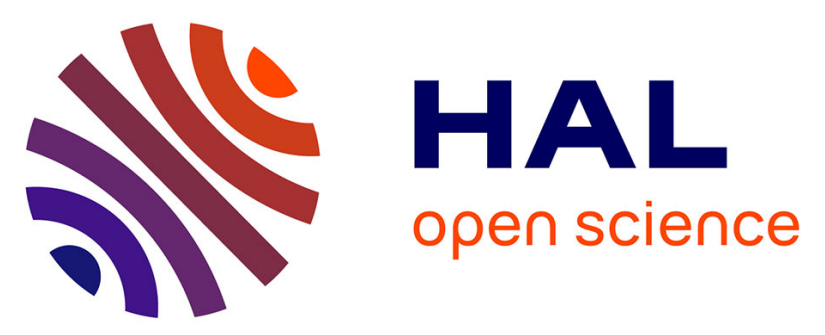

\title{
A revision of the structure and stratigraphy of pre-Green Tuff ignimbrites at Pantelleria (Strait of Sicily)
}

Silvio G. Rotolo, Stéphane Scaillet, Sonia La Felice, Grazia Vita-Scaillet

\section{- To cite this version:}

Silvio G. Rotolo, Stéphane Scaillet, Sonia La Felice, Grazia Vita-Scaillet. A revision of the structure and stratigraphy of pre-Green Tuff ignimbrites at Pantelleria (Strait of Sicily). Journal of Volcanology and Geothermal Research, 2013, 250, pp.61-74. 10.1016/j.jvolgeores.2012.10.009 . insu-00829754

\section{HAL Id: insu-00829754 \\ https://hal-insu.archives-ouvertes.fr/insu-00829754}

Submitted on 6 Jun 2013

HAL is a multi-disciplinary open access archive for the deposit and dissemination of scientific research documents, whether they are published or not. The documents may come from teaching and research institutions in France or abroad, or from public or private research centers.
L'archive ouverte pluridisciplinaire HAL, est destinée au dépôt et à la diffusion de documents scientifiques de niveau recherche, publiés ou non, émanant des établissements d'enseignement et de recherche français ou étrangers, des laboratoires publics ou privés. 


\title{
A revision of the structure and stratigraphy of pre-Green Tuff ignimbrites at Pantelleria (Strait of Sicily)
}

\author{
S.G. Rotolo ${ }^{\left(\mathbf{a}, \mathbf{b}^{*}\right)}$, S. Scaillet ${ }^{(\mathbf{c}, \mathbf{d})}$, S. La Felice ${ }^{(\mathbf{a})}$, G. Vita-Scaillet ${ }^{(\mathbf{c}, \mathbf{d})}$
}

(Published in Journal of Volcanology and Geothermal Research 250 (2013) 61-74)

(a) Dip. Scienze della Terra e del Mare (DiSTeM), Università di Palermo, Via Archirafi 22, 90123 Palermo, Italy

(b) Istituto Nazionale di Geofisica e Vulcanologia (INGV), Sezione di Palermo, Via U. La Malfa 153, 90146 Palermo, Italy

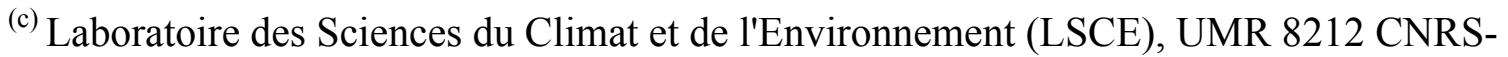
CEA-UVSQ, l'Orme des Merisier, 91191 Gif sur Yvette, France

(d) Now at: Institut des Sciences de la Terre d'Orléans (ISTO) - INSU-CNRS - Université d'Orléans, Observatoire des Sciences de l'Univers en région Centre, Campus Géosciences, 1A rue de la Férollerie, 45071 Orléans Cedex 2, France

* Corresponding author. Tel.: + 39091 23861608; fax: + 390916169908.

E mail address: silvio.rotolo@unipa.it 


\section{Abstract}

At Pantelleria, peralkaline silicic magmas were erupted across a range of eruptive typologies and magnitudes: pyroclastic flows, Plinian to strombolian pumice fallout and lava flows. In this paper we focus on the intermediate cycle of eruptive activity which is bracketed by ignimbrite units slightly older than the two caldera collapses that marked the volcanological history of the island. This age interval (181 - $85 \mathrm{ka})$ was punctuated by six ignimbrite-forming eruptions (silicic and variably peralkaline) for a cumulative erupted magma volume around 6 $\mathrm{km}^{3}$ dense rock equivalent. Based on new ${ }^{40} \mathrm{Ar} /{ }^{39} \mathrm{Ar}(\mathrm{Na}, \mathrm{K})$-feldspar ages and petrographic data, we propose an updated volcanostratigraphic scheme for these welded and rheomorphic ignimbrites that can be summarized as follows: (i) the age of the old ('La Vecchia') caldera collapse is now tightly constrained between 139-146 ka and the caldera-forming eruption can be traced to a lithic-rich welded tuff breccia that outcrops in two opposite sectors of the island; (ii) four ignimbrite units previously considered unrelated are now merged in two distinct eruptive paroxysmal events at 107 and $85 \mathrm{ka}$ of which they represent different facies. In particular, the $85 \mathrm{ka}$ eruptive event is comparable in magnitude to the younger (caldera forming) Green Tuff Plinian eruption; (iii) the recurrence patterns of the 107 and 85 ka eruptions, compared to the Green Tuff, allow us to qualitatively assess that the climax in production of low-temperature silicic and peralkaline melt was focused in the age interval between 85-45 ka.

Keywords: Pantelleria; ignimbrites; pantellerites; peralkaline magmas; ${ }^{40} \mathrm{Ar} /{ }^{39} \mathrm{Ar}$ dating. 


\section{Introduction}

Pantelleria is a peralkaline volcanic complex with a long-lasting volcanological history characterized by a great variety of eruptive styles organized in three successive cycles. The first (324-180 ka) and the last cycles (45-8 ka) share as a common feature the occurence of low-magnitude explosive eruptions and lava flows of peralkaline (i.e. $\mathrm{Na}+\mathrm{K} / \mathrm{Al}>1$ ) magma, mostly represented by pantellerite rocks (a Fe,Cl-rich peralkaline rhyolite). In contrast, the intermediate cycle (180-45 ka) was characterized by at least eight highly explosive eruptions that produced widespread ignimbrite sheets (silicic and variably peralkaline in composition), the youngest being the Plinian eruption of the Green Tuff (45-50 ka).

The study of the ignimbrite sheets older than the Green Tuff is complicated by their lateral discontinuity and because of extensive welding and rheomorphism. Both processes are known to affect high-grade silicic ignimbrites (e.g., Walker, 1983; Branney et al., 2004 ; Andrews and Branney, 2011) but, at Pantelleria, they are widespread across the entire dynamical spectrum (from low-energy Strombolian eruptions to higher-energy Plinian outburts) due to alkali excess over alumina coupled to the high-chlorine content lowering their viscosity by several orders of magnitude (Mahood, 1984). Welding and rheomorphism commonly erase distinctive primary features (textural, structural) of primary deposits (lamination, grading, juveniles/lithic proportions, crystal abundance and internal discontinuities), a circumstance that has variably hampered previous reconstructions and landbased correlations of major units, including the evaluation of the volumes erupted and the magnitude of each eruption (Mahood and Hildreth, 1986). Available geochronological data derived from K-Ar determinations are not very helpful in this connection due to their limitations in terms of accuracy and vulnerability to excess/xenocrystic contamination (Scaillet et al., 2011).

In spite of these limitations, Pantelleria provides a unique study case for the reconstruction of a long-lived, highly eruptive, center that has been active since at least $330 \mathrm{ka}$ with more than 10 major ignimbrite-forming eruptions (Mahood and Hildreth, 1986). Our understanding of the volcanologic evolution of the island has improved steadily since the extensive field work of Mahood and Hildreth (1986), who proposed a stratigraphic scheme still valid for many aspects. Recently, paleomagnetic directional analysis was applied to correlate several pre-50 ka pyroclastic rocks, but the study was limited by the impossibility to 
assign absolute ages to the correlated units (Speranza et al., 2012). A high precision ${ }^{40} \mathrm{Ar} /{ }^{39} \mathrm{Ar}$ study (Scaillet et al., 2011) was also focused on the last activity cycle $(<30 \mathrm{ka})$ to refine the post-Green Tuff evolution of the complex. At last, pre-eruptive conditions of the felsic magma - which are preliminar to any consideration regarding eruptive dynamics and volcanic hazard were recently investigated in some petrology-oriented papers (Rotolo et al., 2007; White et al., 2009; Gioncada and Landi 2010; Neave et al., 2012) or experimental petrology (Di Carlo et al., 2010) that suggest low temperature $\left(730-800^{\circ} \mathrm{C}\right)$ at rather $\mathrm{H}_{2} \mathrm{O}$-rich pre-eruptive conditions ( $\leq 4.5 \mathrm{wt} \%$ ) along with magma accumulation in a superficial reservoir (4-6 km in depth).

Yet, several aspects still remain poorly constrained, especially regarding the mutual relationships between successive ignimbrite events, their correlation across the island and, ultimately, the time-integrated growth of the edifice in terms of magma throughput and repose intervals. Based on newly acquired field and petrographic data complemented by ${ }^{40} \mathrm{Ar} /{ }^{39} \mathrm{Ar}$ ages detailed elsewhere (Scaillet et al., in progress), the goal of this study is to provide a reconstruction of the major ignimbrite units predating the Green Tuff eruption. Our specific aims are:

- to update previous eruption ages by using high precision ${ }^{40} \mathrm{Ar} /{ }^{39} \mathrm{Ar}$ ages;

- to correlate ignimbrite units with no physical continuity in order to clarify some uncertain points in the existing stratigraphy;

- to try estimate the volumes involved and the magnitude of each eruption;

- to more accurately constrain one major caldera-forming eruption and the age of the corresponding caldera collapse (La Vecchia caldera);

- to provide an accurate age control for the paleomagnetic correlations recently proposed by Speranza et al. (2012);

- to explore the recurrence pattern and the time-integrated magma production/discharge rate of the major ignimbrite-forming eruptions.

\section{Eruptive history of Pantelleria}

Pantelleria is a volcanic island, located within the continental rift of the Sicily Strait (Fig. 1) (Rotolo et al., 2006; Civile et al., 2008), and the type-locality of pantellerite rocks. The structure of the island is dominated by two nested calderas (Mahood and Hildreth, 1983): (i) The La Vecchia caldera, dated by K-Ar between $106 \mathrm{ka}$ and $175 \mathrm{ka}$ (Mahood and Hildreth, 1986), or 
alternatively 130-160 ka using paleomagnetic correlation methods (Speranza et al., 2012); the age is bracketed in both cases by the (post-caldera) unit lapping onto the caldera wall and the (precaldera) unit truncated by the caldera collapse. (ii) The younger Cinque Denti caldera (or Monastero caldera, Civetta et al., 1984) is associated with the Green Tuff Plinian eruption dated at 45-50 $\pm 5 \mathrm{ka}$ (Mahood and Hildreth, 1986; Civetta et al., 1988). The Green Tuff (GT) is a low aspect-ratio (Walker, 1983) compound ignimbrite that blankets the whole island and represents the last high(est)-magnitude eruption (Plinian) on the island.

The volcanological history of Pantelleria island and the related eruptive styles can be broadly summarized in three major cycles:

1) Cycle I (324-180 ka), produced mostly pantelleritic lava flows with alternating welded tuffs and local pumice fallout deposits (Mahood and Hildreth, 1986). Extensive burial by younger deposits precludes any reliable inference of the magma volumes erupted during this cycle.

2) Cycle II (180-45 ka), characterized by several explosive eruptions comprising more than eight ignimbrite-forming eruptions, including the La Vecchia caldera-forming eruption (Mahood and Hildreth, 1986; Speranza et al., 2012) and ending with the eruption of the Green Tuff and the related caldera collapse. Besides these island-wide ignimbrites, a number of low-volume strombolian-type pumice fall deposits also occur. The total erupted magma volume over this cycle can be approximated in the range $8-12 \mathrm{~km}^{3}$ D.R.E. (dense rock equivalent).

3) Cycle III (45-8 ka), which includes more than 50 low-energy strombolian eruptions of pantellerite pumice, pantellerite lava flows or lava domes (Civetta et al.,1988; Rotolo et al., 2007 and references therein; Speranza et al., 2010; Scaillet et al., 2011). Late-stage extracaldera basaltic effusives (scoria cones and lava flows) also occur, but these are limited to the North-West side of the island. The total erupted magma volume for this cycle is $\leq 5 \mathrm{~km}^{3}$, D.R.E. (Civetta et al., 1988).

\section{Methods and results}

3.1 Analytical methods 
Whole rock chips were washed and left overnight in distilled water to remove traces of marine aerosol, were then analysed for major and trace elements by X-ray fluorescence on pressed powder pellets (Rigaku Primus XRF spectrometer). Mineral phases were analysed with an OXFORD LEO SEM-EDS, using natural and synthetic standards for quantitative analyses. Operating conditions were: accelerating voltage $=20 \mathrm{kV}$, beam current $=600 \mathrm{pA}$. Routine daily analyses on a standard glass resulted in an analytical uncertainty $(1 \sigma)$ that is: $<1 \%$ for $\mathrm{SiO}_{2}$ and $\mathrm{Al}_{2} \mathrm{O}_{3},<6 \%$ for $\mathrm{FeO}, \mathrm{MgO}, \mathrm{CaO}, \mathrm{Na}_{2} \mathrm{O}, \mathrm{K}_{2} \mathrm{O} .{ }^{40} \mathrm{Ar} /{ }^{39} \mathrm{Ar}$ ages were obtained on anorthoclase separates (on the 0.25-0.5 and 0.5 -1 mm size fractions) using laser extraction techniques detailed in Scaillet et al. $(2008,2011)$.

3.2 Major ignimbrite units at Pantelleria: summary of previous work and new geochronological and petrographic data

Due to systematic mantling by the Green Tuff, Cycle I and II deposits are mostly, if not exclusively, exposed along sea-cliffs or in the lee-side of the caldera walls (Fig. 1, Table 1), hampering their recognition and correlation across the island. In this section we outline the general features of the ignimbrite units that are the focus of this paper, including field relationships, previous K/Ar ages (Mahood and Hildreth, 1986) and new petrographic data (La Felice, 2008); these latter consist of whole-rock XRF analyses and mineral analyses by SEMEDS on polished thin sections (summary in Table 2). Microanalyses probed generally phenocryst/microphenocryst rims, avoiding microlites given the frequent occurence of vapourphase crystallization of aegirine, amphibole, feldspar.

Particular reference is made to the companion work (Scaillet et al., in progress), detailing the new ${ }^{40} \mathrm{Ar} /{ }^{39} \mathrm{Ar}$ anorthoclase ages used to build a refined volcanostratigraphic scheme of the studied sequence. The new ${ }^{40} \mathrm{Ar} /{ }^{39} \mathrm{Ar}$ data are summarized in Table 1. Field details on the key stratigraphic sections are given in the Appendix A. To facilitate the comparison with previous work, the original unit nomenclature of Mahood and Hidreth (1986) is retained throughout

As a common character, all the study ignimbrites are thoroughly welded and, almost invariably, show a variably developed basal vitrophyre, i.e. an obsidian-like quenched base (Fig. 2) (Quane and Russell, 2005). The ignimbrite units can be divided into three groups, from oldest to youngest: 
(1) pre-La Vecchia caldera group (units M and S).

Unit $\mathrm{M}$ forms with the overlying welded tuff $\mathrm{S}$ a typical couplet in the south sector of the island, both being clearly truncated by, and predating the, La Vecchia caldera collapse (Fig. 3, Appendix A). The mean K/Ar age of Unit M (Mahood and Hildreth, 1986) is $174.8 \pm 5.6$ (errors throughout are $2 \sigma$ ), resulting from ages in the range $169 \pm 20 \mathrm{ka}$ and $178 \pm 10 \mathrm{ka}$. This unit is up to $20 \mathrm{~m}$ thick at Salto La Vecchia, where it appears massive with a lithic-rich ground layer (up to $25 \mathrm{~cm}$ thick) with lithics abundance gradually decreasing upwards (to $<2 \%$ ). This is a distinctly crystal-rich rock (25-30 volume \% of seriate-textured phenocrysts), with alkali feldspar up to 7 $\mathrm{mm}$ in length. The whole rock composition (Table 2$)$ is comenditic/trachyte $(\mathrm{Na}+\mathrm{K} / \mathrm{Al}=1.03)$. Clinopyroxene ( $\leq 1 \mathrm{~mm}$ in length, Fs $=22-28 \mathrm{~mol} \%)$ is the second most abundant phase after feldspar. Minor amounts of Fe-rich olivine ( $\leq 0.5 \mathrm{~mm}$ in length, Fo 17-18 mol \%). Quartz phenocrysts are rare and deeply embayed. Phenocrysts are set in a thoroughly devitrified (recrystallized) groundmass.

Unit $\mathrm{S}$ has discordant $\mathrm{K} / \mathrm{Ar}$ ages ranging from $209 \pm 12 \mathrm{ka}$ to $162 \pm 16 \mathrm{ka}$ (Table 1) leaving its age uncertain, with the younger bracket apparently confirmed by the more precise ${ }^{40} \mathrm{Ar} /{ }^{39} \mathrm{Ar}$ age of $171.5 \pm 1.7 \mathrm{ka}$ (Table 1). This unit, around $8 \mathrm{~m}$ thick, is fines-rich and massive in the basal 40-60 cm, then becomes clearly stratified and increasingly laminated in the upper two thirds. Lithic fragments are scarce $(<5 \%$, decreasing upwards to $<2 \%$ ), generally elongate and can reach a maximum length of $30 \mathrm{~cm}$. Petrographically, it is a crystal-rich comendite $((\mathrm{Na}+\mathrm{K}) / \mathrm{Al}=$ 1.13, Table 2) with phenocrysts (up to 35-40 volume \%) of alkali feldspar (up to $3 \mathrm{~mm}$ across), clinopyroxene $(\leq 1 \mathrm{~mm}$ in length, Fs $=23-30 \mathrm{~mol} \%)$ and Fe-rich olivine $(\leq 0.8 \mathrm{~mm}$ in length, Fo 14-19 mol \%). Phenocrysts are all set in a thoroughly devitrified (recrystallized) groundmass.

(2) Syn-La Vecchia caldera group: lithic-rich tuffs to welded pyroclastic breccia units.

The welded breccia unit, Cala Cinque Denti, is a previously undated welded pyroclastic breccia underlying Unit P discussed further below (br 1 in Fig. 4a, Appendix A), with an exposed thickness around $3 \mathrm{~m}$, the base of which is not visible being buried by talus or lying below the sea level. This unit consists of a chaotic mixture of trachy/comenditic angular to subrounded lithic blocks (to $80 \mathrm{~cm}$ in length) strongly, to locally moderately, welded by interspersed flattened glass-rich and vesiculated juvenile scoriae (vesicles $\leq 60$ volume $\%$ and up to $60 \mathrm{~cm}$ in length). 
The latter are trachy-comendites $((\mathrm{Na}+\mathrm{K}) / \mathrm{Al}=1.07)$, with sparse phenocrysts of alkali feldspar $(\leq 4 \mathrm{~mm})$, olivine $(\leq 0.5 \mathrm{~mm}, \mathrm{Fo}=18-22 \mathrm{~mol} \%)$ and clinopyroxene $(\leq 0.5 \mathrm{~mm}, \mathrm{Fs}=28-30 \mathrm{~mol}$ $\%$ ). The ${ }^{40} \mathrm{Ar} /{ }^{39} \mathrm{Ar}$ age for the juvenile scoria is $145.5 \pm 1.3 \mathrm{ka}$ (Table 1, sample 2BR 1).

The welded tuff breccia unit, Cala delle Capre, is a strongly welded tuff-breccia (br 1 in Fig. 4b and Appendix A) exposed in vertical cliffs at three locations in the south-west and south of the island. It underlies unit $\mathrm{F}$ and, most importantly, directly overlies the remnants of the La Vecchia caldera rim (and unit M) with a $30^{\circ}-40^{\circ}$ inland dip (barely visible in Fig. 4b). The existing $\mathrm{K} / \mathrm{Ar}$ ages are quite imprecise $(104 \pm 106 \mathrm{ka}, 127 \pm 74 \mathrm{ka}$, Table 1$)$, but similar to the much more precise ${ }^{40} \mathrm{Ar} /{ }^{39} \mathrm{Ar}$ estimate of $139.2 \pm 1.6 \mathrm{ka}$ (Table 1). The thickness of this unit is maximum at Cala delle Capre $(20 \mathrm{~m})$ and decreases rapidly towards South East: it is around $1 \mathrm{~m}$ thick in the vertical scar of Cala della Posata (2.5 km South-East of Cala delle Capre, Fig. 1), and 50-60 cm thick below unit F at Salto La Vecchia (3 km South-East of Cala delle Capre).

At Cala delle Capre, the basal portion (4-5 m thick) of this unit consist of welded juvenile flattened scoriae and is very lithic-rich (50-60\%) with angular to subrounded clasts up to $60 \mathrm{~cm}$ in diameter, the lithics decreasing in abundance up section (to 10-20\%). Juvenile scoriae are crystal-rich (phenocrysts 30-40 volume \%) and vesicle-poor ( $\leq 15$ volume \%) is comenditic $((\mathrm{Na}+\mathrm{K}) / \mathrm{Al}=1.19)$ with alkali feldspar phenocrysts (up to $5 \mathrm{~mm}$ in length) that coexist with a Fe-rich olivine ( $\leq 1 \mathrm{~mm}$ in length, Fo 7-8 $\mathrm{mol} \%$ ), clinopyroxene (up to $2 \mathrm{~mm}$ in length, Fs $=42-$ $44 \mathrm{~mol} \%$ ), ilmenite, pyrrothite and apatite.

(3) Post-La Vecchia caldera group (and pre-Green Tuff): Units P, Q, F, D, Z.

Unit $\mathrm{P}$ is a crystal-rich, welded and rheomorphic ignimbrite, discontinuously exposed in the North-East to North-West of the island (Fig. 5). At Lago di Venere, Unit P is the lowest of three ignimbrites that outcrop along the roadcut (Fig. 6a, 6b, Appendix A). K/Ar ages are tightly grouped (Table 1) at $133.1 \pm 6.6 \mathrm{ka}$. Conversely, ${ }^{40} \mathrm{Ar} /{ }^{39} \mathrm{Ar}$ ages vary between $134.9 \pm 1.2 \mathrm{ka}$ and $123.0 \pm 1.6 \mathrm{ka}$ (Table 1), with a mean of $128.6 \pm 5.9 \mathrm{ka}$. This is a comenditic ignimbrite $(\mathrm{Na}+\mathrm{K} / \mathrm{Al}=1.19-1.22)$, crystal-rich (phenocrysts $\geq 30$ volume \%) with alkali feldspars varying in size from 6 to $13 \mathrm{~mm}$, olivine $(\leq 0.5 \mathrm{~mm}$ in length, Fo $=22-34 \mathrm{~mol} \%)$ and clinopyroxene $(\leq$ $0.5 \mathrm{~mm}$ in length, Fs $=26-30 \mathrm{~mol} \%$ ), (Fig. 7). Microphenocrysts of brown amphibole occur in accessory amounts and are set in a patchy recrystallized groundmass. 
Unit $\mathrm{Q}$ is a 8 to $>13 \mathrm{~m}$ thick, rheomorphic and crystal-rich ignimbrite (phenocrysts $=30$ 35 volume \%) that resembles Unit P in several aspects and outcrops only in a few sites in the North and East (according to Mahood and Hildreth, 1986). The pooled K/Ar age is $113.9 \pm 7.2 \mathrm{ka}$ (Mahood and Hildreth, 1986) while ${ }^{40} \mathrm{Ar} /{ }^{39} \mathrm{Ar}$ dating yielded $114.3 \pm 1.0 \mathrm{ka}$ (Table 1). Compositionally, it is a comendite $((\mathrm{Na}+\mathrm{K}) / \mathrm{Al}=1.26)$, with typically shattered alkali feldspar phenocrysts up to $4 \mathrm{~mm}$ in length, set in a glassy, flow-banded, matrix. Clinopyroxene (up to 0.5 $\mathrm{mm}$ in length) composition is in the range $\mathrm{Fs}=30-35 \mathrm{~mol} \%$, while olivine (up to $0.4 \mathrm{~mm}$ in length) is Fo $=13-16 \mathrm{~mol} \%$, the rare quartz phenocrysts are thoroughly lobate.

Pumice fall unit: in a few places of the North to North-east of the island, a fine grained pumice fallout deposit is found interleaved between units $\mathrm{P}$ and F (Fig. 5, 6a). The thickness of this deposit ranges from few $\mathrm{cm}$ at P.ta Guardia to $2.5 \mathrm{~m}$ at Lago (Appendix A). Pumices clasts (2-4 cm in length) contain sparse phenocrysts of alkali feldspar (to $5 \mathrm{~mm}$ in lenght), and fewer clinopyroxene (to $3 \mathrm{~mm}$ in length, Fs = 23-32 mol \%); the glassy groundmass, variably devitrified and altered, has a comendite composition. Lithics are principally angular hyalopantellerites $\leq 1.5 \mathrm{~cm}$ in length.

Unit $\mathrm{F}$ is a fines-rich and crystal-poor (phenocrysts $<15-20$ volume \%) massive ignimbrite ( $0.8-7 \mathrm{~m}$ thick), extensively exposed throughout the island (with the exception of the West and South-East) below unit Z. Three K/Ar ages (Mahood and Hildreth, 1986) constrain the age of unit $\mathrm{F}$ at $105.7 \pm 7 \mathrm{ka}$, while its ${ }^{40} \mathrm{Ar} /{ }^{39} \mathrm{Ar}$ age is $107.1 \pm 0.7 \mathrm{ka}$ (Table 1). Whole rock composition is pantelleritic $((\mathrm{Na}+\mathrm{K}) / \mathrm{Al}=1.40)$, with alkali feldspar as the most abundant phenocrystic phase ( 2 to $4 \mathrm{~mm}$ in length, followed by subhedral olivine (up to $1 \mathrm{~mm}$ in length, Fo $=12-14 \mathrm{~mol} \%$ ) and clinopyroxene (up to $0.8 \mathrm{~mm}$ in length $\mathrm{Fs}=25-32 \mathrm{~mol} \%$ ). The groundmass is generally glassy and slightly to moderately devitrified. Above Unit F, at Bue Marino, and at Lago (ca. $2.5 \mathrm{~km}$ apart), there occurs, in apparent continuity, a strongly to moderately welded breccia (br 2 in Fig. 8a, Appendix A), whose thickness (4 $\mathrm{m}$ to $80 \mathrm{~cm}$ ) and lithic clasts size (30 to $15 \mathrm{~cm}$ ) decrease northwards (cf. Fig. $6 \mathrm{~b}$ and $8 \mathrm{a}$ ).

Unit $\mathrm{D}$ is a 5 to $10 \mathrm{~m}$ thick ignimbrite, discontinuously exposed along the North-East coastline (Fig. 5). It is massive, crystal-poor (phenocrysts $\leq 15$ volume $\%$ ) and characterized by a fine grained, glass-rich, matrix with rare black/reddish angular lithic fragments. The K/Ar ages range from $88 \pm 16 \mathrm{ka}$ to $97 \pm 12 \mathrm{ka}$ (Mahood and Hildreth, 1986) while the ${ }^{40} \mathrm{Ar} /{ }^{39} \mathrm{Ar}$ ages are concordant and tightly grouped at $86.1 \pm 1.9 \mathrm{ka}$ to $86.8 \pm 1.3 \mathrm{ka}$ (Table 1). Compositionally, it 
straddles the comendite/pantellerite fields $((\mathrm{Na}+\mathrm{K}) / \mathrm{Al}=1.26-1.29)$. Alkali feldspar has a maximum length of $3 \mathrm{~mm}$ and is the dominant phenocrystic phase, followed by olivine (to 0.5 $\mathrm{mm}$ in length, Fo $=21-23 \mathrm{~mol} \%$ ) and clinopyroxene (to $0.5 \mathrm{~mm}$ in length, Fs $=23-36 \mathrm{~mol} \%$ ). The groundmass consists of thoroughly welded glass shards and fiamme.

Unit $\mathrm{Z}$ is the most widespread ignimbrite on the island (after the GT) and is also the sole among those studied with clearly recognizable members (flow units). Unit $\mathrm{Z}$ crops out around the island with very different mesoscopic patterns: (i) in the type-section east of Bue Marino it consists of a $7 \mathrm{~m}$ thick sequence composed of discrete flow subunits alternating fines-rich with pumice lapilli-rich members (Fig. 8a, Appendix A); (ii) in South outcrops unit Z is $1 \mathrm{~m}$ thick (Fig. 3), obsidian-like, but porphyritic (phenocrysts $\leq 20$ volume \%); (iii) inland, e.g. on the caldera scarp at Zinedi (Fig. 8b, Appendix A), it contains alternating lithic-rich and fines-rich laminated layers, for a total thickness $\leq 8 \mathrm{~m} . \mathrm{K} / \mathrm{Ar}$ ages are in the range $78 \pm 10$ to $84 \pm 22 \mathrm{ka}$ (Table 1). ${ }^{40} \mathrm{Ar} /{ }^{39} \mathrm{Ar}$ ages are much more accurate at $83.9 \pm 0.7 \mathrm{ka}$ and $85.2 \pm 1.7 \mathrm{ka}$ (Table 1). The bulk rock composition varies from comendite to pantellerite, with the $(\mathrm{Na}+\mathrm{K}) / \mathrm{Al}$ in the range 1.15-1.40, the highest value corresponding to the basal vitrophyric member. Phenocryst content is generally low to very low (20 to $<10$ volume \%). Alkali feldspar phenocrysts (up to a maximum length of $4 \mathrm{~mm}$ ) are distinctly shattered and are followed in abundance by clinopyroxene (up to $1 \mathrm{~mm}$ in length, Fs $=26-36 \mathrm{~mol} \%$ ) and olivine (up to $1 \mathrm{~mm}$ in length, Fo = 21-23 mol \%). The groundmass is glassy with sparse microlites of alkali feldspar.

\section{Discussion}

\subsection{Correlation of ignimbrite units}

The most comprehensive attempt at constraining the pre-Green Tuff stratigraphy, after the initial work by Wright (1980), was the extensive work of Mahood and Hildreth (1986) who recognized at least eight ignimbrite units/welded tuffs (plus a number of minor uncorrelated pumice fall deposits) on the basis of a detailed field logging/mapping complemented by a large number of $\mathrm{K} / \mathrm{Ar}$ ages (34 spiked extractions). This work provided a detailed basis for later studies, including the present survey, along with a working template and nomenclature for assigning the different units recognized so far (Table 1). While our own data concur for most part with the early stratigraphic reconstruction of Mahood and Hildreth (1986), they do suggest, 
however, the reassignment of units with uncertain attribution and/or questionable age or correlation. In particular, some pending issues were left unsolved by earlier studies, including:

1) the identification of the La Vecchia caldera-forming eruption and the more precise age of the collapse within the proposed brackets 106-175 ka: Mahood and Hildreth (1986) suggested the caldera-forming eruption was represented either by unit Q $(\mathrm{K}-\mathrm{Ar}=113.9 \pm$ $7.2 \mathrm{ka}$ ) or by the lithic-rich welded tuff at Cala delle Capre (potentially equivalent to Unit $\mathrm{Q}$ in their stratigraphic scheme), which has a poorly constrained K-Ar age of $120 \pm 60 \mathrm{ka}$.

2) Units $P$ and $Q$ are found as continuous outcrop together at three localities (Lago di Venere, Gadir and Pozzolana) but are mutually exclusive elsewhere, hindering their precise correlation.

3) The doublets Q-F and D-Z, were distinguished on the basis of some petrographic characteristics but their constitutive units are mutually exclusive at all sections studied and do not differ significantly (pairwise) in their K-Ar range (Mahood and Hildreth, 1986): Q ranges in the interval $104-116 \mathrm{ka}$ ( $\pm 28 \mathrm{ka}$, mean individual $2 \sigma$ error $), \mathrm{F}=101-110 \mathrm{ka}( \pm 14$ $\mathrm{ka}) . \mathrm{D}$ was dated in the range $=88-97( \pm 16 \mathrm{ka})$ and $\mathrm{Z}$ in the range 78-84 $( \pm 22 \mathrm{ka})$, suggesting thus the possibility that these four units might actually represent only two units (i.e. $\mathrm{Q}=\mathrm{F}$ and $\mathrm{D}=\mathrm{Z}$ ).

Part of these ambiguities were solved Speranza et al. (2012) on the basis of a systematic characterization of paleomagnetic directional variations recorded by the different ignimbrites. Altough this method does not provide absolute ages for rocks older than $10 \mathrm{ka}$ (the paleosecular variation curve is well constrained only for Holocene), it is a powerful tool to correlate synchronous eruptive units. The reason being that coeval units must share similar paleomagnetic directions, given that the local geomagnetic field undergoes continuous variations with time (although it might reoccupy the same position over some thousands years) and these can be detected with a resolution close to 100-200 years (Speranza et al., 2012). The most relevant results from Speranza et al. (2012) can be summarized in the following points:

1) the welded tuff breccia at Cala delle Capre (below unit F) was found to correlate with the welded pyroclastic breccia at Cala Cinque Denti (below unit P), both being considered related to the La Vecchia caldera-forming eruption. The age bracketing of the caldera 
collapse was consequently tightened between the pre-caldera unit $\mathrm{M}(\mathrm{K} / \mathrm{Ar}$ age $=174.8 \pm$ $5.6 \mathrm{ka})$, and the post-caldera unit $\mathrm{P}(\mathrm{K} / \mathrm{Ar}$ age $=133.1 \pm 6.6 \mathrm{ka})$, defining a most probable age interval between 130-160 ka.

2) The actual significance of unit $Q$ was questioned: the lowest ignimbrite East of Bue Marino, previously considered belonging to Unit Q by Mahood and Hildreth (1986), was assigned to Unit P. Likewise, at C. Pozzolana only Unit P is present, with two cooling units, and not P and Q as stated by Mahood and Hildreth (1986).

3) Units $D$ and $Z$ share fully consistent paleomagnetic orientations suggesting a similar (if not common) age.

Our study allows us to further refine this framework by integrating field-based observations as well as whole-rock and mineral compositional data, with the fourteen new ${ }^{40} \mathrm{Ar} /{ }^{39} \mathrm{Ar}$ ages reported in Table 1. We illustrate below the pooled results for the various ignimbrites units, from oldest to youngest, among the stratigraphic sections detailed in Appendix A. The resulting revised correlation scheme is portrayed in Fig. 9.

(i) Welded Breccia/tuff breccia units (Br 1, 139-145 ka)

${ }^{40} \mathrm{Ar} /{ }^{39} \mathrm{Ar}$ ages of the two welded breccia /welded tuff breccia that occur in opposite sectors of the island ( $8 \mathrm{~km}$ apart: Cala Cinque Denti and Cala delle Capre) display an age difference (6.3 ka) twice as large as the sum of quoted errors $( \pm 1.3, \pm 1.6 \mathrm{ka})$. The differences in age might reflect slight variations in xenocrystic contamination, with the younger of the two ages more closely approaching the true age of eruption and deposition (hence of the caldera collapse), at ca. $140 \pm 2 \mathrm{ka}$.

(ii) Units $\mathrm{P}, \mathrm{Q}$, and F

Unit P: three ${ }^{40} \mathrm{Ar} /{ }^{39} \mathrm{Ar}$ ages obtained from Unit $\mathrm{P}$ are scattered in the range $123.0 \pm 1.6 \mathrm{ka}$ to $134.9 \pm 1.2 \mathrm{ka}$. The internal age distribution of the two samples $1 \mathrm{P}, 3 \mathrm{P}(134.9 \pm 1.2 \mathrm{ka}$ and $128.1 \pm 1.4 \mathrm{ka}$, respectively) is quite scattered with ages as old as $170 \mathrm{ka}$ and $220 \mathrm{ka}$ (Scaillet et al., in progress) reflecting severe xenocrystic contamination. Sample 2P is instead characterized 
by a well-defined probability peak at $123.0 \pm 1.6 \mathrm{ka}$ and this we take as the most probable cooling age of unit P (Table 1).

The Pumice fall unit: the fine-grained comenditic pumice fall deposit occupies the same stratigraphic position above Unit P and below Unit F (Fig. 9) at Bue Marino, Cinque Denti and Lago. We might also speculate on the possible correlation with the fine grained pumice fall found at Cala delle Capre below Unit F and above the welded breccia (Fig. 4b). The dispersion of this deposit over a maximum outcrop exposure $>3 \mathrm{~km}$ (or $>6 \mathrm{~km}$ if correlative with the fall at Cala delle Capre) may suggest a sub-Plinian/Plinian eruption. Based on available evidence, we can constrain the eruption age of this pumice fall in the interval 107-123 ka bracketed by Units $\mathrm{F}$ and $\mathrm{P}$, respectively.

Unit Q: the ignimbrite previously considered as Unit Q unit that at Lago di Venere, overlies the fine grained pumice fall just mentioned, and was dated by ${ }^{40} \mathrm{Ar} /{ }^{39} \mathrm{Ar}$ at $114.3 \pm 1.0 \mathrm{ka}$ (see below the discussion on unit F). The interval between the eruptions of $\mathrm{P}$ and $\mathrm{Q}$ is very short compared to the other ignimbrites $(8.7 \mathrm{ka}$, only the F-Q time gap being shorter: $7.1 \mathrm{ka})$. At Cala Levante, the lower ignimbrite of the sequence (Fig. 10), which was originally assigned to unit Q by Mahood and Hildreth (1986) and dated by K/Ar at $113 \pm 10 \mathrm{ka}$ (their sample 26), returned a much older ${ }^{40} \mathrm{Ar} /{ }^{39} \mathrm{Ar}$ age of $181.2 \pm 1.2 \mathrm{ka}$. As a consequence, we tentatively reassign this unit to the pre-La Vecchia unit M.

Unit $\mathrm{F}$ : the ${ }^{40} \mathrm{Ar} /{ }^{39} \mathrm{Ar}$ age of $107.1 \pm 0.7 \mathrm{ka}$ is very close to the age unit $\mathrm{Q}$ and both units share also compatible paleomagnetic orientations (Speranza et al., 2012) and similar petrographic features. Importantly, Q and F were found in direct contact (i.e. superposed) by Mahood and Hildreth (1986) only in the North of the island (Cala Bue Marino to Punta della Guardia), that is, in those sites where unit Q was reassigned to unit P by Speranza et al. (2012), with the obvious consequence that $\mathrm{F}$ and $\mathrm{Q}$ are never seen in direct superposition. The above considerations suggest that the former Unit Q could represent an East-directed crystal-rich flow lobe of the coeval low aspect-ratio and fines-rich ignimbrite F, which largely blanketed the island. Altough not explicitly stated in Speranza et al (2012), is worth noting that units Q and F show very close paleomagnetic directions (their Fig. 7), strengthening our conclusion on the Q-F equivalence.

The slightly older age of sample $3 \mathrm{Q}$ with respect to $1 \mathrm{~F}(114.3 \pm 1.0 \mathrm{vs} .107 .1 \pm 0.7 \mathrm{ka}$, respectively) is most likely due to xenocrystic contamination in the crystal-rich Q flow Unit 
(Scaillet et al., in progress). We consequently consider $107 \mathrm{ka}$ as the eruption age of unit F-Q. As a corollary, we speculate that the welded breccia (br 2) east of Bue Marino, could correlate with the (variably welded) breccia at Lago, given their same stratigraphic position above unit $\mathrm{F}$ (Appendix A).

(iii) Units D and Z

Our data point out that Units $\mathrm{D}$ and $\mathrm{Z}$ are coeval and also petrographically similar. In fact, while the previous $\mathrm{K} / \mathrm{Ar}$ ages were dissimilar (but unresolved within error limits: i.e. $\mathrm{D}=93.9 \pm$ $9.4 \mathrm{ka}$ and $\mathrm{Z}=79.3 \pm 8.4 \mathrm{ka}$, Table 1 ), this difference drops below the $2 \sigma$ level with the new ${ }^{40} \mathrm{Ar} /{ }^{39} \mathrm{Ar}$ ages: $86.1-86.7 \pm 1.8 \mathrm{ka}$ for unit $\mathrm{D}$ and $83.9-85.2 \pm 1.7 \mathrm{ka}$ for $\mathrm{Z}$. Our results are consistent with the identical paleomagnetic directions found for both units by Speranza et al. (2012). As a consequence, at Cala Cinque Denti, Lago di Venere and Gadir, the former unit D must be considered as a fines- and glass-rich facies of unit $\mathrm{Z}$ that propagated eastward. Merging $\mathrm{D}$ and $\mathrm{Z}$ units into a single eruption implies that the event at $85 \mathrm{ka}$ was much more important than hitherto considered.

\subsection{Characterization of parent magmas}

The main problem with the whole rock chemistry of ignimbrites is the possibility that the bulk composition does not strictly represent the former magma, due, inter alia, to the loss of fine ash (elutriation) that results in an apparent increased abundance of phenocrysts. The accumulation of 20 volume \% of $(\mathrm{Na}, \mathrm{K})$-feldspar $\left(\mathrm{Ab}_{66} \mathrm{Or}_{27}\right.$ and $\mathrm{Na}+\mathrm{K} / \mathrm{Al}=0.9$, Romengo, 2011) lowers the bulk rock $(\mathrm{Na}+\mathrm{K}) / \mathrm{Al}$ from 1.40 to 1.2 and also dilutes the concentration of trace elements other than $\mathrm{Ba}, \mathrm{Rb}$. Crystal accumulation due to fines loss is likely to have partially affected some crystal-rich ignimbrites (Units M, S, P, phenocrysts $=25-40$ volume $\%$ ), where the thorough recrystallization of the groundmass (devitrification and vapour phase crystallization) prevents to obtain reliable analyses of groundmass glass.

Two broad groups can be distinguished, (i) the less evolved comenditic trachytes (Units M, P) with a $\mathrm{Na}+\mathrm{K} / \mathrm{Al} \leq 1.22$, and (ii) the relatively more evolved comendites/pantellerites (units $\mathrm{BR} 1, \mathrm{Q} / \mathrm{F}, \mathrm{D} / \mathrm{Z}, \mathrm{Z}$ ) with a $\mathrm{Na}+\mathrm{K} / \mathrm{Al} \geq 1.26$ and Fe-rich olivine (Fo $<16 \%$ ). However, there is not a satisfactory coherence among bulk rock and mineral data, due probably to xenocryst contamination, phenocryst accumulation and glass devitrification. Thus, petro- and mineral- 
chemical data suggest the following points: (i) the magma that fed the less evolved group of ignimbrites has a trachytic to trachy-comenditic composition with pre-eruptive temperatures $\geq$ $900^{\circ} \mathrm{C}$ (White et al.,2009); (ii) the more evolved ignimbrites (comenditic pantellerites to pantellerites) have lower pre-eruptìve temperatures, intermediate between trachytes and pantellerites, these latter having temperatures $\leq 750^{\circ} \mathrm{C}$ (Di Carlo et al., 2010). The above considerations can be complemented with the evidence that peralkaline magmas at Pantelleria cool in relatively superficial magma chambers $(<5 \mathrm{~km}$, Di Carlo et al., 2010; Mattia et al., 2007) and also that, for their high melt water content $\left(\mathrm{H}_{2} \mathrm{O} \leq 4.5 \mathrm{wt} \%\right.$, Di Carlo et al., 2010; Gioncada \& Landi, 2010), vapour exsolution - hence volatile build-up - is expected for P $\geq 0.1 \mathrm{GPa}$, or at depths $\geq 3.5 \mathrm{~km}$.

\subsection{Erupted magma volumes}

Before illustrating our approach to infer erupted magma volumes, it is useful to briefly summarize how previous authors faced this issue for the Green Tuff, which was interpreted either as a welded fall or a compound rheomorphic ignimbrite:

(i) Wolff and Wright (1981), assuming an origin entirely by fallout, inferred a volume of 7 $\mathrm{km}^{3}$ D.R.E., by comparison of the average topography with the welded tuff's dependence of thickness on ground slopes.

(ii) Mahood and Hildreth (1986), on the basis of an exponential law for thinning deposits, (i.e., assuming a dominant fallout origin), calculated a total volume around $3.7 \mathrm{~km}^{3}$ (D.R.E.) distributed as caldera filling $\left(1 \mathrm{~km}^{3}\right.$ D.R.E), extracaldera mantling $\left(0.25 \mathrm{~km}^{3}\right.$ D.R.E), and fallout at sea (around $2.5 \mathrm{~km}^{3}$ D.R.E).

(iii) Alternatively, Civetta et al. (1988) infer, from a mean thickness of $5 \mathrm{~m}$ for extracaldera GT $\left(\right.$ area $\left.=55 \mathrm{~km}^{2}\right)$ and $17 \mathrm{~m}$ for caldera-filling $\left(\right.$ area $\left.=28 \mathrm{~km}^{2}\right)$, an onland volume of 0.75 $\mathrm{km}^{3}$ D.R.E. (mean density $=2000 \mathrm{~kg} / \mathrm{m}^{3}$ ). According to these authors, this volume should be doubled to take in account the amount of coarse tephra that felt in the sea and fine ash dispersal as well.

This variability in volume calculations reflects the uncertainty in volume proxy parameters (thickness, areal extent), that obviously increases for old ignimbrites due to poorer exposure. 
Erupted volumes can be estimated assuming a mean (and constant) thickness seen in available sections ( 3 to 8 for each unit), along with an areal extent interpolated between outcrops. Assuming a mean and constant thickness is a good approximation due to the short horizontal distance from the caldera rim to the coast (the most distal is $2.5 \mathrm{~km}$ ). In discarding either exponential or power-law thinning (see Bonadonna and Costa, 2012), it is also implied that other depositional processes than pure fallout played a dominant role (e.g. progressive aggradation, Branney and Kokelaar, 2002). The linear assumption is supported by the thickness variations of Unit Z: $7 \mathrm{~m}$ on the most distal site from caldera rim $(2.5 \mathrm{~km}$, section east of Bue Marino in Appendix A), $6 \mathrm{~m}$ on the inner caldera wall at Zinedi, and $3 \mathrm{~m}$ in the opposite side of the island (Salto La Vecchia), where however thinning occurred due to ramping over the caldera wall.

The volume estimates can be converted into D.R.E volumes on the basis of a (water-free) magma density of $2380 \mathrm{~kg} / \mathrm{m}^{3}$ (Ochs and Lange, 1999) and a solid rock density variable from 1800 to $2000 \mathrm{~kg} / \mathrm{m}^{3}$ (typical for welded felsic ignimbrites, Orsi and Sheridan, 1984; Quane and Russell, 2005; Folks et al., 2011) with the lower value assigned to the relatively pumice-rich unit Z. In summary:

Unit M: assuming the coverage of the area from Scauri to Cala Levante (Fig. 1), approximately $40 \mathrm{~km}^{2}$, a mean thickness of $12 \mathrm{~m}$ and a bulk density of $2000 \mathrm{~kg} / \mathrm{m}^{3}$ result in a volume estimate of $0.41 \mathrm{~km}^{3}$ D.R.E.

Unit S: taking the same parameters as for Unit M, but with a mean thickness of $10 \mathrm{~m}$, the resulting volume is $0.34 \mathrm{~km}^{3}$ D.R.E.

Unit P: the covered area (Gadir, Bue Marino, Cala Altura, Lago, Fig. 1) is ca. $35 \mathrm{~km}^{2}$ wide, for a mean thickness of $10 \mathrm{~m}$ and a bulk density of $2000 \mathrm{~kg} / \mathrm{m}^{3}$, yielding $0.46 \mathrm{~km}^{3}$ D.R.E.

Unit F: we assume a coverage over more than half the island, excluding the West and South East margins, i.e,. ca. $45 \mathrm{~km}^{2}$, a density of $2000 \mathrm{~kg} / \mathrm{m}^{3}$ and a mean thickness of $5 \mathrm{~m}$. The resulting volume is $0.19 \mathrm{~km}^{3}$ D.R.E.

Unit Z: assuming complete blanketing of the island $\left(83 \mathrm{~km}^{2}\right)$ and a mean thickness of $7 \mathrm{~m}$, a volume of $0.43 \mathrm{~km}^{3}$ D.R.E. can be calculated, assuming a density of $1800 \mathrm{~kg} / \mathrm{m}^{3}$. 
These are areal (onland) estimates only and it is difficult to infer the amount of tephra deposited in the sea and the co-ignimbrite ash loss, which may be significant for the phenocrystrich Units $\mathrm{M}, \mathrm{S}$ and $\mathrm{P}$. Some empirical correction factors were recently proposed to take in account all these sources of bias in the calculation of ignimbrites volume (Folks et al., 2011). We consider that a reasonable, if not minimal, approximation for Pantelleria ignimbrites is to multiply the volumes calculated onland by a factor of 3 (cf., Lipman, 1984). Accordingly, the erupted D.R.E. magma volume change as follows: Unit $\mathrm{M}=1.2 \mathrm{~km}^{3}$; Unit $\mathrm{S}=1.0 \mathrm{~km}^{3}$; Unit $\mathrm{P}=$ $1.3 \mathrm{~km}^{3}$, Unit $\mathrm{F}=0.6 \mathrm{~km}^{3}$; Unit $\mathrm{Z}=1.4 \mathrm{~km}^{3}$, for a cumulative volume of $5.5 \mathrm{~km}^{3}$. We emphasize that these values should be taken with caution given the approximations introduced.

\subsection{Eruptive periodicity and peralkaline melt productivity}

An estimate of magma production rates can be attempted based on the newly defined stratigraphy, depositional chronology and erupted magma volumes. Such an exercice is better constrained for the age interval 107-45 ka (bracketed by Units F, Z, GT). Accordingly, if we take in account the age interval between $\mathrm{F}$ and $\mathrm{Z}(22 \mathrm{ka})$ and the erupted volume of $\mathrm{Z}$, the inferred 1.4 $\mathrm{km}^{3}$ D.R.E. (ignoring all other minor eruptions in the F-Z age interval, due to the low volume of erupted tephra), translates into a melt production rate around $0.06 \mathrm{~km}^{3} / \mathrm{ka}$ of peralkaline acidic magma. The next eruptive interval, between $\mathrm{Z}$ and the Green Tuff (i.e. $35 \mathrm{ka}$, assuming for the GT an age of $50 \mathrm{ka}$ ), can be approximated considering the mean value of the volume estimates for the GT (3.5 $\mathrm{km}^{3}$ D.R.E). This translates into a melt productivity of $0.1 \mathrm{~km}^{3} / \mathrm{ka}$, that should be regarded as a minimum estimate ignoring the volume of magma erupted during this period by the Attalora center, a $250 \mathrm{~m}$ high (above the field level) pumice cone, for a volume $\leq 0.3 \mathrm{~km}^{3}$.

Therefore, during the time interval spanned by the main ignimbrite-forming Cycle II (181$50 \mathrm{ka}$ ), the magma peralkalinity (i.e. magma evolution) apparently increased in the sequence: unit $\mathrm{M}(181 \mathrm{ka} ; \mathrm{Na}+\mathrm{K} / \mathrm{Al}=1.03)$, unit $\mathrm{F}(107 \mathrm{ka} ; \mathrm{Na}+\mathrm{K} / \mathrm{Al}=1.26-1.40)$ to $\mathrm{Z}(85 \mathrm{ka} ; \mathrm{Na}+\mathrm{K} / \mathrm{Al}=$ $1.15-1.40)$ to the Green Tuff $(\mathrm{Na}+\mathrm{K} / \mathrm{Al}=1.7-1.8$, mean of groundmass glass analyses, Romengo, 2011). The increase in peralkalinity during the Cycle II seems also coupled with a peak in melt production culminating with the Green Tuff eruption after the long intereruptive period ( $35 \mathrm{ka}$ ) following the $85 \mathrm{ka}$ eruptive paroxysm.

\section{Summary and conclusions}


By conducting an extensive field-survey complemented by petrographic data and highresolution ${ }^{40} \mathrm{Ar} /{ }^{39} \mathrm{Ar}$ dating, we have refined and better constrained the eruptive chronology of six silicic and peralkaline ignimbrites emplaced in the age interval 181-85 ka. We summarize our main findings as follows.

1) The pre-La Vecchia caldera eruptive history is closed by the two comenditic/trachitic units $\mathrm{M}$ and $\mathrm{S}(181.2 \pm 1.2 \mathrm{ka}$ and $171.5 \pm 1.7 \mathrm{ka}$, respectively), which are exposed only in the South West and South East of the island, both being truncated by the La Vecchia caldera collapse.

2) The La Vecchia caldera-forming eruption has been identified in two opposite sectors of the island in the form of one welded pyroclastic breccia (Cala Cinque Denti, North-East) that correlates with a welded tuff-breccia (Cala delle Capre, South-West), the latter directly overlapping the remnants of the La Vecchia caldera scarp. Their ${ }^{40} \mathrm{Ar} /{ }^{39} \mathrm{Ar}$ ages $(145.5 \pm 1.3$ and $139.2 \pm 1.6 \mathrm{ka}$, respectively) place much tighter constraints on the caldera collapse than provided by previous works.

3) After this caldera collapse, the first ignimbrite eruption occurred at $123 \mathrm{ka}$ as the trachycomenditic crystal-rich unit P covering the North East to North West slopes of the island.

4) The emplacement of unit $P$ was followed by the eruption of a crystal-rich ignimbrite (former unit ' $Q$ ' in the literature) restricted in a rather narrow Eastern portion of the island. We reinterpret unit $\mathrm{Q}$ as a directional flow lobe of the more widely distributed, fines-rich and low aspect-ratio, pantelleritic unit $\mathrm{F}$, both being part of an eruptive climax at around $107 \mathrm{ka}$.

5) Similarly, we demonstrate that the former unit D represents a juvenile- and fines-rich flow lobe that covered the East of the island, and was coeval of the widespread low aspect-ratio unit Z (comenditic/pantelleritic), both being emplaced at $85 \mathrm{ka} \mathrm{BP}$. Merging of these two (previously considered distinct) units defines an eruptive climax comparable to the 45-50 ka Green Tuff Plinian eruption.

6) The analysis of the recurrence time of ignimbrite eruptions allows some qualitative considerations to be made about the production and evolution rates of pantellerite melts. Taken as a whole, the total erupted magma volume in the period $181-85 \mathrm{ka}$, is close to $6 \mathrm{~km}^{3}$ D.R.E. 
suggesting in particular that at the end of the inter-eruptive period 85-45 ka the highest amount of magma coincided with the maximum degree of magma evolution.

\section{Acknowledgements}

This work was partially supported by the 2005-2007 INGV-DPC project 'Pantelleria'. The manuscript greatly benefited from a thorough and helpful review by an anonymous reviewer. One half of the samples, petrographic data and ages, were presented in the PhD thesis of SLF all the other and their elaboration derive from later studies. We wish to thank Fabio Speranza for many helpful discussions and for the "COS"-labeled samples jointly collected with one of us (SGR) during several field campaigns dedicated to paleomagnetic correlations. Thanks are due to Gianni Lanzo for his help in drawing sections. 


\section{References}

Andrews, G.D.M., Branney, MJ., 2011. Emplacement and rheomorphic deformation of a large, lava-like rhyolitic ignimbrite: Grey's Landing, southern Idaho. Geological Society of America Bulletin 123, 725-743.

Bonadonna, C., Costa, A., 2012. Estimating the volume of tephra deposits: a new simple strategy. Geology 40, 415-418.

Branney, M.J., Kokelaar, P., 2002. Pyroclastic density currents and the sedimentation of ignimbrites. Geological Society of London Memoir 27, pp 152.

Branney, M.J., Barry, T.L., Godchaux, M., 2004. Sheathfolds in rheomorphic ignimbrites. Bulletin of Volcanology 66, 485-491. doi:10.1007/s00445-003-0332-8.

Civetta, L., Cornette, Y., Crisci, G., Gillot, P.Y., Orsi, G., Requejo, C. S., 1984. Geology, geochronology and chemical evolution of the island of Pantelleria. Geological Magazine 121, 541-562.

Civetta, L., Cornette, Y., Crisci, G., Gillot, P.Y., Orsi, G., 1988. The eruptive history of Pantelleria (Sicily Channel) in the last $50 \mathrm{ka}$. Bulletin of Volcanology 50, 47-57.

Civile, D., Lodolo, E., Tortorici, L., Lanzafame, G., Brancolini G., 2008. Relationships between magmatism and tectonics in a continental rift: the Pantelleria Island region (Sicily Channel, Italy). Marine Geology 251, 32-46.

Di Carlo, I., Rotolo, S.G., Scaillet, B., Buccheri V., Pichavant, M., 2010. Phase equilibrium constraints on pre-eruptive conditions of recent felsic explosive volcanism at Pantelleria Island, Italy. Journal of Petrology 51, 2245- 2276.

Folks, C.B., Wright, H.M., Cas, R.A.F., De Silva, S.L., Lesti, C., Viramonte, J.G., 2011. A reappraisal of the stratigraphy and volcanology of the Cerro Galàn volcanic system, NW Argentina. In Cas RAF, Cashman K (Eds) The Cerro Galan Ignimbrite and Caldera: characteristics and origin of a very large volume ignimbrite and its magma system. Bulletin of Volcanology 73, 1427-1454.

Gioncada, A., Landi, P., 2010. The pre-eruptive volatile contents of recent basaltic and pantelleritic magmas at Pantelleria (Italy). Journal of Volcanology and Geothermal Research, 189, 191-201.

La Felice S., 2008. Tephrostratigraphy of silicic volcanism at Pantelleria island, combining field observations, petrochemical data and ${ }^{40} \mathrm{Ar} /{ }^{39} \mathrm{Ar}$ dating: implications on magmatic system. $\mathrm{PhD}$ Thesis 209 pp, Università di Palermo.

Lipman, P.W. 1984. The roots of ash flow calderas in western North America: windows into the tops of granitic batholiths. Journal of Geophysical Research, 89, 8801-8841.

Macdonald, R., 1974. Nomenclature and petrochemistry of the peralkaline oversaturated extrusive rocks. Bulletin of Volcanology 38, 498-505.

Mahood, G.A., 1984. Pyroclastic rocks and calderas associated with strongly peralkaline magmatism. Journal of Geophysical Research 89, 8540-8552.

Mahood, G.A., Hildreth W., 1983. Nested calderas and trapdoor uplift at Pantelleria, Strait of Sicily. Geology 11, 103-106.

Mahood, G.A., Hildreth W., 1986. Geology of the peralkaline volcano at Pantelleria, Strait of Sicily. Bulletin of Volcanology 48, 143-172.

Mattia, M., Bonnacorso, A., Guglielmino, F., 2007. Ground deformations in the island of Pantelleria (Italy): insights into the dynamic of the current intereruptive period. Journal of Geophysical Research 112, doi: 10.1029/2006JB004781.

Neave,D.A., Fabbro, G., Herd, R.A., Petrone, C.M., Edmonds M., 2012. Melting, differentiation and degassing at the Pantelleria volcano, Italy. Journal of Petrology 53, 637-663. 
Ochs, F.A., Lanhe R.A., 1999. The density of hydrous magmatic liquids. Science 283, 1314-1317.

Quane, S.L., Russell, J.K., 2005. Ranking welding intensity in pyroclastic deposits. Bulletin of Volcanology 67, 129-143.

Romengo N. 2011. Relationships between mafic and felsic magmatism at Pantelleria: a petrological study on intermediate trachyte magmas. $\mathrm{PhD}$ Thesis, University of Palermo.

Rotolo, S.G., Castorina, F., Cellura, D., Pompilio, M., 2006. Petrology and geochemistry of submarine volcanism in the Sicily Channel Rift. Journal of Geology 114, 355-365.

Rotolo,S.G., La Felice, S., Mangalaviti, A., Landi, P. 2007. Geology and petrochemistry of the recent $(<25 \mathrm{ka})$ silicic volcanism at Pantelleria island. Bollettino Società Geologica Italiana 126, 191-208.

Scaillet S., Vita-Scaillet G., Guillou H. (2008) Oldest human footprints dated by ${ }^{40} \mathrm{Ar} /{ }^{39} \mathrm{Ar}$. Earth. Planet. Sci. Lett. 275: 320-325.

Scaillet, S., Rotolo, S.G, La Felice, S., Vita, G., 2011. High-resolution ${ }^{40} \mathrm{Ar} /{ }^{39} \mathrm{Ar}$ chronostratigraphy of the post-caldera $(<20 \mathrm{ka})$ volcanic activity at Pantelleria, Sicily Strait. Earth and Planetary Science Letters 309, 280-290. doi:10.1016/j.eps1.2011.07.009.

Speranza, F., Landi, P., D’Ajello Caracciolo, F., Pignatelli, A., 2010. Paleomagnetic dating of the most recent silicic eruptive activity at Pantelleria (Strait of Sicily). Bulletin of Volcanology $72,847-858$.

Speranza, F., Di Chiara, A., Rotolo, S.G., 2012. Correlation of welded ignimbrites on Pantelleria, using paleomagnetism. Bulletin of Volcanology 74, 341- 357. doi: 10.1007/s00445-011-05219.

Sumner, J.M., Branney, M.J., 2002. The emplacement history of a remarkable heterogeneous, chemically zoned, rheomorphic and locally lava-like ignimbrite: 'TL' on Gran Canaria. Journal of Volcanology and Geothermal Research 115,109-138.

Walker, G.P.L., 1983. Ignimbrite types and ignimbrite problems, Journal of Volcanology and Geothermal Research 17, 65-88.

White, J.C., Parker, D.F., Ren, M., 2009. The origin of trachytes and pantellerite from Pantelleria, Italy: Insights from major element, trace element and thermodynamic modelling. Journal of Volcanology and Geothermal Research 179, 33-55.

Wolff, J.A. Wright J.V., 1981. Formation of the Green Tuff, Pantelleria. Bulletin of Volcanology 44, 681-690.

Wright, J.V., 1980. Stratigraphy and geology of the welded air-fall tuffs of Pantelleria, Italy. Geologische Rundschau 1, 263-291. 


\section{Figure captions}

Fig. 1. Simplified geological map of Pantelleria island (modified after Mahood and Hildreth, 1986, and Scaillet et al., 2011). Numbers refer to sampling sites reported in Tables 1,2 .

Fig. 2. Microphoto of a basal vitrophyre (plane polarized light, magnification $40 \mathrm{X}$, Unit Z), characterized by the maximum degree of welding, within each ignimbrite. Note the stretched former pumiceous clast (lower half) and smaller quenched glass shards flattened and adherent to one another (upper half).

Fig. 3. Salto La Vecchia, facing East: the old caldera scarp cuts obliquely through the pre-caldera units $\mathrm{M}$ and $\mathrm{S}$ (sample $6 \mathrm{~S}$, Table 1). $\mathrm{Br} 1$ is a welded tuff-breccia (50 cm thick) that crops out in the bottom of the exposed caldera wall and correlates with the welded breccia at Cala delle Capre (see Fig. 4b), and represents the caldera-forming eruption. Postcaldera units $\mathrm{F}$ and $\mathrm{Z}$ (sample $6 \mathrm{Z},{ }^{40} \mathrm{Ar} /{ }^{39} \mathrm{Ar}$ age $=85.2 \pm 1.7 \mathrm{ka}$ ) lap onto (and extend beyond) the caldera wall. The Attalora pumice fall (Att) was erupted from the nearby Attalora centre (K-Ar $=69 \pm 18 \mathrm{ka}$, Mahood and Hildreth, 1986). The Green Tuff (GT) occurs here in two flow units (the upper one with evident rheomorphic folds) and is characterized by a large rheomorphic thickening towards the bottom of a paleovalley (left of photo).

Fig. 4. a) Cala Cinque Denti, facing North: the welded pyroclastic breccia (br 1, sample $2 \mathrm{BR},{ }^{40} \mathrm{Ar} /{ }^{39} \mathrm{Ar}$ age $=145.5 \pm 1.3 \mathrm{ka}$ ) below Unit $\mathrm{P}$ correlates with the welded tuff breccia of Cala delle Capre (Fig. 4b), in the opposite side of the island, and both are related to the La Vecchia caldera collapse. $\mathrm{P}$ and $\mathrm{Z}$ units are characterized by a 30-40 cm thick welded coignimbrite breccia at their base. b) Cala delle Capre: the dark-red welded tuff-breccia (br 1, sample $7 \mathrm{BR},{ }^{40} \mathrm{Ar} /{ }^{39} \mathrm{Ar}$ age $=139.2 \pm 1.6 \mathrm{ka}$ ) lies over the caldera rim (i.e., onto pre-caldera Unit $\mathrm{M}$, visible in the background at the right). BR 1 unit is overlain by a thin and finegrained pumice fall (f) which in turn is capped by units F, Z, Green Tuff the succession ending with a young pantellerite lava flow erupted from the Cuddie Bellizzi vents.

Fig. 5. Cala Cinque Denti, facing South, showing the caldera wall that cuting across the pre-caldera ignimbrite units: P (sample 2 P) a fine grained pumice fall (f) and Z (former unit D of Mahood and Hildreth, 1986; our sample 2 D/Z). A thin veener of the Green Tuff (GT) 
caps the sequence, while a young pantellerite lava flow (lav) erupted from the Cuddia Randazzo vent, banks against, and spills over, the caldera wall.

Fig. 6. a) Lago di Venere, lower section: ignimbrite P (sample $3 \mathrm{P}$ ) is separated from unit F (former unit Q, sample 3 Q) by a fine-grained pumice fall (f). b) Lago di Venere upper section: the fine-grained pumice fall underlies ignimbrite $\mathrm{F}$ which in turn is overlain by a $4 \mathrm{~m}$ thick poorly welded breccia (br 2). Higher up, unit Z (former unit D, sample $3 \mathrm{Z}$ ) and the Green Tuff (GT).

Fig. 7. Petrographic aspects of Unit $\mathrm{P}$ (plane polarized light, magnification $40 \mathrm{X}$ ). Mineral assemblage in a glomerophyric aggregate: Fe-clinopyroxene (cpx) is patchy zoned (Fe-poor areas are colorless, Fe-rich are light green) and hosts Fe-Ti oxides and apatite needles; olivine (ol) has an opaque rim (composed of Fe-rich amphibole and aenigmatite). Fsp is the hosting alkali feldspar.

Fig. 8. a) East of Cala Bue Marino: ignimbrite F (sample $1 \mathrm{~F}$ ) overlies the crystal-rich ignimbrite $\mathrm{P}$ (former unit $\mathrm{Q}$, not visible in the picture, sample $1 \mathrm{P}$ ). Unit $\mathrm{F}$ shows at its top a gradual fading into the welded breccia (br 2) thought to be correlative of the breccia at Lago (Fig. 6b). Higher up, unit Z (sample 1 Z) occurs with its basal vitrophyre and alternating fines-rich and pumice-rich members. The Green Tuff and a young basaltic lava flow cap the section (not visible in the Figure). b) Costa Zinedi: the inner side of the Cinque Denti caldera wall. Unit Z (sample 4 Z), the same that at Salto La Vecchia laps onto the (La Vecchia) caldera scarp (Fig. 3), and is truncated here by the younger Cinque Denti collapse. Note the veneer of Green Tuff that mantles discordantly $\mathrm{P}$ and $\mathrm{Z}$ units, flowing backwards towards the caldera center (left of the photo).

Fig. 9. Island-scale correlation of eruptive units throughout the key stratigraphic sections sampled for this study. For more detailed descriptions of the individual sections refer to Appendix A. Heading numbers on the columns allow to locate them on Fig. 1 and Table 1 $(1$ = East of Bue Marino; 2 = Cala Cinque Denti; 3 = Lago di Venere; 4 = Zinedi; 5 = Cala Levante; $6=$ Salto La Vecchia; $7=$ Cala delle Capre). Units M, S, P, F, Z and GT are in capitals. Bas = basaltic lava flow; $\mathrm{Br} 1=$ welded tuff-breccia; $\mathrm{f}=$ pumice fallout; $\mathrm{f}$ Att $=$ pumice fall and lava erupted from Cuddia Attalora; lav = pantellerite lava flow. Numbers in red represent the ${ }^{40} \mathrm{Ar} /{ }^{39} \mathrm{Ar}$ ages of the dated units for each site (see Table 1 for details). $\mathrm{a}=$ 
Cinque Denti caldera rim; $\mathrm{b}=\mathrm{La}$ Vecchia caldera rim; $\mathrm{c}=$ coincident Cinque Denti and La Vecchia rims; $\mathrm{d}=$ paleosoil.

Fig. 10 Cala Levante: at the bottom Unit M, sample $5 \mathrm{M}$ (former Unit Q of Mahood and Hildreth, 1986), upsequence unit Z (former Unit D) and the Green Tuff at the top. 


\section{APPENDIX A \\ Description of key stratigraphic sections}

We detail here the key stratigraphic sections sampled for this study. Section numbers refer to their location in Fig. 1, to locate study samples in the sections and to correlate eruptive units between sections refer to Table 1 and Fig. 9, respectively.

SECTION 1, East of Bue Marino (Fig. 1). Eruptive units from bottom to top: P, fall, soil, F, breccia 2, Z, GT, basaltic lava.

The exposed sequence (partially represented in Fig. 8a) starts from the sea-level with unit P (former Unit Q of Mahood and Hildreth, 1986), here with diffuse rheomorphic folds, with a thickness of at least $15 \mathrm{~m}$, base not visible. P is very crystal-rich (up to 35 volume per cent) with alkali feldpar phenocrysts up to $13 \mathrm{~mm}$ in length (

Higher up, above an erosion surface that marks the end of P, a 20-30 cm-thick deeply weathered reddish zone occurs with a still recognizable fine-grained pumice fall (pumice clasts $\leq 1.5 \mathrm{~cm}$ ), fines-rich and with hyalopantellerite lithics (length $=1 .=\leq 3 \mathrm{~mm}$ ) and abundant loose crystals of alkali feldspar and clinopyroxene $(1 . \leq 3 \mathrm{~mm})$.

Follows unit $\mathbf{F}$ which is generally fines-rich, crystal-poor $(\leq 15$ volume per cent, with alkali feldspar, $1 . \leq 4 \mathrm{~mm}$ ) and lithic-poor, for an overall thickness of $2.2 \mathrm{~m}$. F begins with a well developed basal vitrophyr, $10 \mathrm{~cm}$ thick, above being characterized by a slightly lower degree of welding (i.e. sparse fiamme) at half height of the deposit is visible an alignment of lithic clast (length $\leq 40 \mathrm{~cm}$ ). In the upper half of the deposit flattened pumice clasts (diameter $\leq 10 \mathrm{~cm}$ ) are recognizable within the fine grained matrix. The upper portion fades into a 20$80 \mathrm{~cm}$ thick poorly-sorted, welded breccia (br 2), whose lithic clasts reach a maximum length of $20 \mathrm{~cm}$. Above the breccia a sharp discontinuity marks the transition with the overlying unit $Z$.

Unit $\mathbf{Z}$ displays in this locality its maximum thickness $(7 \mathrm{~m})$ and shows the following clearly distinguishable members: (a) a glass-rich and crystal-poor basal vitrophyre $(10-25 \mathrm{~cm}$ thick), peppered with frequent fine-grained holocrystalline lithics (diameter $=2-4 \mathrm{~cm}$ ) alkali feldspar-rich (comagmatic intrusive pantellerites).

Just avobe the vitrophyre, occur flattened glassy pantelleritic or crystal rich trachytic lithics (to $10 \mathrm{~cm}$ ); (b) a 40-60 $\mathrm{cm}$ thick member enriched in pumice lapilli (diameter up to 6 $\mathrm{cm}$ ), strongly scavenged by the sea-water alteration (Fig. 8a), with rare lithics up to $5 \mathrm{~cm}$; (c) a 1.5-2 m thick member fines-rich and lithic-free; (d) a topmost member (1 m thick) enriched in pumice lapilli as the lower member. This is a crystal-poor ignimbrite, phenocrysts $\leq 15$ volume per cent, (with alkali feldpar, $1 . \leq$ $4 \mathrm{~mm}$ ) altough the cristal content varies slightly in the various members, being richer in the pumice-rich members.

The Green Tuff follows above unit $Z$ and with a thickness of 1.5 to $5 \mathrm{~m}$ (variation due to rheomorphic thickening in paleovalleys). The basal vitrophyre grades into the pistachio-green main member, moderately crystal-rich (feldspars up to $4 \mathrm{~mm}$ ). The sequence is topped by a young scoriaceous basaltic lava flow.

SECTION 2, Cala Cinque Denti (welded breccia 1, $P$, fall, $F, Z, G T$, pantellerite lava).

The welded breccia (br1) unit crops out only in the North side of Cala Cinque Denti (Fig. 5) with a thickness of at least $3 \mathrm{~m}$, base not seen. The breccia consists of flattened spatter lumps (up to $60 \mathrm{~cm}$ in length) of trachytic-comenditic, crystal-poor and vesicle-rich juveniles and subordinate angular to subrounded lithic clasts, up to $80 \mathrm{~cm}$ in length, all variably welded in a fine grained glassy matrix material with sparse alkali feldspar crystals. 
Follows Unit $\mathbf{P}$ ( 8 to $10 \mathrm{~m}$ thick) with a $30 \mathrm{~cm}$ basal lag breccia composed of subrounded lithics (to $20 \mathrm{~cm}$ in diameter) thoroughly welded in the ignimbrite matrix. This latter is crystal-rich (phenocrysts content $25-30$ volume per cent) with alkali feldspar $1 . \leq 11 \mathrm{~mm}$. The upper half of the deposit shows convolute to recumbent rheomorphic folds, which conversely are absent in the lower half.

Above unit $\mathrm{P}$ occurs a $80 \mathrm{~cm}$ thick rather poorly sorted pumice fall (weathered: reddish to yellow in colour). Pumice clasts are rather dense with a maximum length is $2 \mathrm{~cm}$, crystallinity is low with phenocrysts of alkali feldspar $(1 . \leq 5 \mathrm{~mm})$ and clinopyroxene $(1 . \leq 3$ $\mathrm{mm})$. Rare lithics of aphyric hyalopantellerites are $<1 \mathrm{~cm}$ in diameter, while become more abundant in the size class $<3 \mathrm{~mm}$, together withy loose crystals (alkali feldspar, pyroxene).

Higher up with a sharp transition, there is a $40 \mathrm{~cm}$ thick massive and fines-rich welded tuff (tentatively assigned to Unit F); these two latter units are visible only in the south wall (looking NE) of Cala Cinque Denti.

Higher up, unit $\mathbf{Z}$ (former Unit D of Mahood and Hildreth, 1986) has an overall thickness of 6-7 $\mathrm{m}$ and begins with a welded lag-breccia member, composed of sub-rounded to slightly elongate lithics up to $30 \mathrm{~cm}$ in diameter, that fades into a welded ignimbrite glassrich and crystal-poor ( $\leq 20$ volume per cent, alkali feldspar up to $4 \mathrm{~mm}$ ). Similarly with the underlying Unit $\mathrm{P}$, the upper half of $\mathrm{Z}$ shows extensive rheomorphic folding, unlike its lower half.

The Green Tuff tops the sequence with a thickness $<1 \mathrm{~m}$. The succession is capped by a young pantellerite lava flow erupted from the Cuddia Randazzo vent.

\section{SECTION 3, Lago di Venere (P, fall, F, breccia 2, Z, GT).}

The sequence is exposed in the roadcut to the Lake and begins with unit $\mathbf{P}$ with a thickness $>15 \mathrm{~m}$, base not visible, (Figs. 6a, 6b), this is a lithic-poor ignimbrite (lithics $<5$ $\mathrm{cm}$ ), distinctly rheomorphic in its upper half. Phenocryst content is around 35 volume per cent, with alkali feldspar crystals up to $7 \mathrm{~mm}$ in length, and set in a variably devitrified matrix.

The upper irregular surface of $\mathrm{P}$ is mantled by a $2.5 \mathrm{~m}$ thick rather poorly sorted, finespoor, pumice fall deposit. The diameter of pumice clasts is $\leq 4 \mathrm{~cm}$; these are crystal-poor with alkali feldspar and pyroxene $(1 . \leq 4 \mathrm{~mm})$. Lithics are moderately abundant $<1 \mathrm{~cm}$ in length and consist of aphyric hyalopantellerite lithics. Loose crystals of alkali feldspar (to 6 $\mathrm{mm}$ ) are instead abundant. The top of this fall deposit, that correlates with the fall at Cinque Denti and east of Bue Marino, is reddish likely due to heating-oxidation following the emplacement of the overlying ignimbrite $\mathrm{F}$.

Unit F (former Unit Q of Mahood and Hildreth, 1986) has a total thickness of $6 \mathrm{~m}$ and begins with a massive and fines-rich, crystal-poor $40 \mathrm{~cm}$ thick basal member, that grades into a crystal-rich member (30-35 volume per cent) with alkali feldpar phenocrysts up to $6 \mathrm{~mm}$.

Above F occurs a $4 \mathrm{~m}$ thick lithic breccia (br 2) with rounded to subangular clasts up to $40 \mathrm{~cm}$ in their maximum length, that marks the transition with the overlying unit Z. Welding is moderate to strong for the first meter and decreases higher up, together with increasing roundness of the clasts.

Unit Z (former unit D of Mahood and Hildreth, 1986) consists of a fines-rich and crystalfree lower member (thickness $\leq 1 \mathrm{~m}$ ), slightly laminated in the first $50 \mathrm{~cm}$, that becomes rather massive above, when grades into the main member, more porphyritic (phenocrysts up to 15 volume per cent) and slightly rheomorphic. The overall thickness is $4 \mathrm{~m}$.

Higher up, the Green Tuff (around $2 \mathrm{~m}$ thick) mantles discordantly unit Z, this latter clearly truncated by the young caldera collapse. The lower portion of the Green Tuff begins with a few $\mathrm{cm}$ thick pumice fallout followed by a thin $(5 \mathrm{~cm})$ vitrophyre, enriched in juvenile spatter lumps (to $12 \mathrm{~cm}$ in length). 
SECTION 4, Zinedi ( $P$, fall, soil, Z, GT).

We detail here the topmost $30 \mathrm{~m}$ of the section (Fig. 8b) that ends at the caldera crest at Zinedi, the lower portion of the section being covered by talus. The sequence starts with Unit $\mathbf{P}$, here deeply weathered, for an exposed thickness $>5 \mathrm{~m}$ (the base is not visible). As commonly observed elsewhere, $\mathrm{P}$ is crystal-rich (35-40 volume per cent) with alkali feldspar phenocryst up to $10 \mathrm{~mm}$.

Above $\mathrm{P}$ follows a $80 \mathrm{~cm}$ thick fine-grained and weathered fall deposit which is followed by a compact reddish paleosoil, $50 \mathrm{~cm}$ thick, rich in lithics and loose crystals. Above, the transition to Unit $\mathbf{Z}$ is sharp. As a whole, unit $Z$ (as thick as $6 \mathrm{~m}$ ) is crystal-poor $(\leq 20$ volume per cent), with alkali feldspar up to $3 \mathrm{~mm}$ in size. The basal member is rich in streaky fiamme and is followed by a lithic-rich layer $(1 \mathrm{~m}$ thick, with rounded lithics up to $15 \mathrm{~cm}$ in length). In this location, $Z$ is characterized by a peculiar sawtooth erosional profile due to alternating prominent glass-rich layers $(2-10 \mathrm{~cm}$ thick the each) with more eroded fines-rich levels $(10-30 \mathrm{~cm}$ the each). The upper portion of $\mathrm{Z}(1 \mathrm{~m}$ thick) is distinctly lithic-rich, with subrounded lithics up to $15 \mathrm{~cm}$ in diameter.

Above a weathered zone follows the Green Tuff ( 1 to $5 \mathrm{~m}$ thick) that mantles discordantly the collapse-truncated sub-horizontal layers of Z (Fig. 8b). The base of the GT consists of a thin $(<10 \mathrm{~cm})$ layer of the early-erupted pumice fall, fine grained and well sorted, with pumice lapilli $\leq 3 \mathrm{~cm}$ in length. This fallout member outcrops only in few outcrops of the east portion of the island. Above the basal fall there is a $10 \mathrm{~cm}$ thick vitrophyre. The sequence continues with the welded main body of the Green Tuff.

\section{SECTION 5, Cala Levante (M, Z, GT).}

The study section is $200 \mathrm{~m}$ North of the Punta dell' Elefante locality.

From sea level to a height between 5-10 m, an ignimbrite unit (the base is below the sea level) yielded ages much older $\left({ }^{40} \mathrm{Ar} /{ }^{39} \mathrm{Ar}\right.$ age $\left.=181 \mathrm{ka}\right)$ than Unit $\mathrm{Q}$, to which it was previously assigned by Mahood and Hildreth (1986); we thus tentativey assign this ignimbrite to unit M. This unit at Cala Levante is crystal-rich and massive with large alkali feldspar crystals (phenocrysts $=25-30$ volume per cent, to a maximum size of $3 \mathrm{~mm}$; clinopyroxene $\leq$ $1 \mathrm{~mm}$, olivine $\leq 0.5 \mathrm{~mm}$ ). The lower exposed portion shows some alignement of eutaxitic fiamme. Lithics are poorly abundant and $<5 \mathrm{~cm}$ in diameter. The top portion is reddish, weathered, and marks the transition towards the overlying ignimbrite $\mathbf{Z}$ (former Unit $\mathbf{D}$ of Mahood and Hildreth, 1986). This latter has an overall thickness of 5-6 m and begins with a thin vitrophyre $(\leq 5 \mathrm{~cm})$; the upper portion is rather massive, altough a crude lamination can be distinguished, due principally to the strong sea water alteration that preferentially eroded glass-rich layers. Phenocryst content is $\leq 20$ volume per cent, with alkali feldspar $\leq 3-5 \mathrm{~mm}$ in length. Lithics are abundant and small $(2-5 \mathrm{~cm})$ in the lower half, mostly consisting of holocrystalline microsyenites. The upper half of the unit is less lithic rich and shows distinct rheomorphic folding.

The sequence is topped by the Green Tuff, up to $4 \mathrm{~m}$ thick, that starts with a basal vitrophyre $5-15 \mathrm{~cm}$ thick and continues with the main ignimbrite body without any clear internal structure.

\section{$G T)$}

SECTION 6, Salto La Vecchia (M, soil, S, welded tuff breccia, F, soil, Z, fall Attalora,

The section at Salto La Vecchia (Fig. 3), is clearly divided in two discordant sectors by the caldera wall. The right-hand side in Fig 3 (i.e. South) consists of pre-caldera Units $\mathrm{M}$ and $\mathrm{S}$, both truncated by the La Vecchia caldera collapse; the caldera wall is steep $\left(\geq 60^{\circ}\right)$ but not 
vertical, suggesting that some erosional retreat occurred before the caldera wall was "sealed" by the first post-caldera unit.

The sequence begins with the lithic-rich ground layer (40 cm thick) of unit M, whose overall thickness is $20 \mathrm{~m} . \mathrm{M}$ is a massive and crystal-rich ignimbrite (phenocrysts $=25-30$ volume per cent), with alkali feldpars up to $7 \mathrm{~mm}$ in length. The lithic abundance (diameter < $10 \mathrm{~cm}$ ) gradually decreases upwards (to $<2$ volume per cent).

The transition to the overlying unit $\mathbf{S}$ is through a reddish weathered zone ( $70 \mathrm{~cm}$ thick) partly humified in its lower portion. Unit $\mathbf{S}$ is a $8 \mathrm{~m}$ thick, thickly laminated and crystal-rich ignimbrite (35-40 volume per cent) with alkali feldspars to $3 \mathrm{~mm}$ in size. Lithics $(<5$ per cent, decreasing upwards to $<2$ per cent), are variably elongate up to $30 \mathrm{~cm}$ in length

Syn- to post-caldera units, i.e. those lapping the north side of the caldera wall, begin with a welded tuff-breccia (br 1) (50-60 cm thick) that correlates with the welded tuff breccia of Cala delle Capre. Altough a close visual inspection proved impossible, given the occurence in the middle of a vertical scar, this unit consists of lithic clasts up to $20 \mathrm{~cm}$ in diameter, strongly welded within the glass-rich blackish matrix. Above this unit are visible sparse remnants (max thickness $20 \mathrm{~cm}$ ) of a minute pumice fall, locally apparently weathered (reddish).

Follows Unit F, characterized by a thickness variable from $2 \mathrm{~m}$ at the exposed bottom of the caldera wall, up to $40 \mathrm{~cm}$ over the caldera crest. $\mathrm{F}$ is fines- and glass- rich and distinctly laminated.

The transition with the overlying Unit $\mathbf{Z}$ occurs through a few $\mathrm{cm}$ thick reddish paleosoil. As for unit $F, Z$ thickens rheomorphically from $60 \mathrm{~cm}$ to $3 \mathrm{~m}$. At Salto La Vecchia $Z$ is represented by a unique member very glass-rich, obsidian-like, and crystal poor ( $\leq 15$ volume per cent).

Above $\mathrm{Z}$, the sequence continues with a local pumice fall deposit visible only in the West side of Salto La Vecchia, which has a maximum thickness of $25 \mathrm{~m}$; the pumice fall is topped by a pantellerite lava flow, both members having being erupted by the nearby Attalora volcano.

The Green Tuff closes the sequence and is characterized by extreme thickness variations ( 1 to $15 \mathrm{~m}$ ), due to rheomorphism, and also by its occurence in two flow units, the lower massive, the higher with ample rheomorphic folds.

SECTION 7, Cala delle Capre (M, welded tuff-breccia, fall, F, Z, GT, pantellerite lava).

We describe the sequence visible in the Fig $\mathbf{4 b}$, starting from a height of $30 \mathrm{~m}$ a.s.l., above the talus that covers some older uncorrelated tuffs and fall deposits onto which lies unit M. From this height, just above $M$ and the remnants of the caldera scarp gently dipping inwards, the sequence continues with a welded tuff-breccia (br 1) that consists from the base, and for the first 4-5 m, of alternating agglutinated flattened juvenile scoriae $(40-60 \mathrm{~cm}$ in length) with angular to subrounded lithic clasts $(20-60 \mathrm{~cm}$ in diameter), thoroughly welded. Higher up (the overall thickness is $20 \mathrm{~m}$ ) the spattered material becomes dominant over lithics; the matrix between clasts is crystal-rich and welding becomes even stronger. Importantly, this unit laps the remnants of the caldera wall with an inland dipping (i.e. East) surface and just below the the pre-caldera unit $\mathrm{M}$.

Above the welded breccia unit, there is a $1 \mathrm{~m}$ thick fine-grained (clasts diameter $<2 \mathrm{~cm}$ ) and poorly sorted pumice fall (fines-rich), which in turn is overlain by unit F. This latter has a total thickness of $8 \mathrm{~m}$, with the first $10 \mathrm{~cm}$ characterized by the basal vitrophyre that continues upward into a massive, fines-rich, lithic- and crystal-poor main member.

Up section, unit $\mathbf{Z}$, with a $10 \mathrm{~cm}$ basal vitrophyre and a total thickness around $7 \mathrm{~m}$ with the lower half being massive and the upper half crudely laminated. The Green Tuff tops $Z$ with a thickness varying from 5 to $8 \mathrm{~m}$. At the very top, the sequence is closed by a young pantellerite lava flow erupted from the nearby vents of Cuddie Bellizzi. 
Table 1

\begin{tabular}{|c|c|c|c|c|c|c|}
\hline $\begin{array}{l}\text { Site } \\
n^{\circ}\end{array}$ & $\begin{array}{l}\text { Sampling } \\
\text { site } \\
\text { (2) }\end{array}$ & $\begin{array}{l}\text { Sample } \\
\text { ID }\end{array}$ & Field/lab \# & $\begin{array}{l}\text { Previously assigned } \\
\text { Unit and } \mathrm{K}-\mathrm{Ar} \text { age } \\
\qquad(\mathrm{ka} \pm 2 \sigma) \\
\text { (5) }\end{array}$ & $\begin{array}{c}{ }^{40} \mathrm{Ar} /{ }^{39} \mathrm{Ar} \text { age } \\
(\mathrm{ka} \pm 2 \sigma) \\
(6)\end{array}$ & $\begin{array}{c}\text { Unit } \\
\text { assignment, } \\
\text { and eruption } \\
\text { age (ka), this } \\
\text { work }\end{array}$ \\
\hline \multirow[t]{3}{*}{1} & $\begin{array}{l}\text { South East } \\
\text { of Cala Bue }\end{array}$ & $1 \mathrm{P}$ & $\cos 15$ & $P=133.1 \pm 6.6$ & $134.9 \pm 1.2$ & $P=123$ \\
\hline & & $1 \mathrm{~F}$ & PAN 0676 & $\mathrm{~F}=105.7 \pm 7.0$ & $107.1 \pm 0.7$ & $F=107$ \\
\hline & & $1 \mathrm{Z}$ & PAN 0675 & $Z=79.3 \pm 8.4$ & $83.9 \pm 0.7$ & $Z=85$ \\
\hline \multirow[t]{3}{*}{2} & $\begin{array}{l}\text { Cala Cinque } \\
\text { Denti }\end{array}$ & 2 BR 1 & COS 32 & & $145.5 \pm 1.3$ & $\mathrm{BR}=146$ \\
\hline & & $2 \mathrm{P}$ & PAN 0656 & $P=133.1 \pm 6.6$ & $123.0 \pm 1.6$ & $\mathrm{P}=123$ \\
\hline & & $2 \mathrm{D}$ & PAN 0655 & $\mathrm{D}=93.9 \pm 9$ & $86.1 \pm 1.9$ & $Z=85$ \\
\hline \multirow[t]{3}{*}{3} & $\begin{array}{l}\text { Lago di } \\
\text { Venere }\end{array}$ & $3 \mathrm{P}$ & $\cos 24$ & $P=133.1 \pm 6.6$ & $128.1 \pm 1.4$ & $\mathrm{P}=123$ \\
\hline & & $3 \mathrm{Q}$ & PAN 0713 & $\mathrm{Q}=113.9 \pm 7.2$ & $114.3 \pm 1.0$ & $\mathrm{~F}=107$ \\
\hline & & $3 \mathrm{D}$ & PAN 0712 & & $86.8 \pm 1.3$ & $Z=85$ \\
\hline 4 & Zinedi & $4 \mathrm{Z}$ & PAN 0654 & $Z=79.3 \pm 8.4$ & $84.4 \pm 1.4$ & $Z=85$ \\
\hline 5 & $\begin{array}{l}\text { Cala di } \\
\text { Levante }\end{array}$ & $5 \mathrm{M}$ & Q LEV & $Q=113.9 \pm 7.2$ & $181.2 \pm 1.2$ & $\mathrm{M} ?=181$ \\
\hline \multirow[t]{2}{*}{6} & $\begin{array}{l}\text { Salto La } \\
\text { Vecchia }\end{array}$ & $6 \mathrm{~S}$ & PAN 0651 & $\begin{array}{c}S=163(162 \pm 16- \\
209 \pm 12)\end{array}$ & $171.5 \pm 1.7$ & $S=172$ \\
\hline & & $6 \mathrm{Z}$ & PAN 0652 & $Z=79.3 \pm 8.4$ & $85.2 \pm 1.7$ & $Z=85$ \\
\hline 7 & $\begin{array}{l}\text { Cala delle } \\
\text { Capre }\end{array}$ & 7 BR 1 & COS 31 & $104 \pm 106,127 \pm 74$ & $139.2 \pm 1.6$ & $\mathrm{BR}=139$ \\
\hline
\end{tabular}

\section{TABLE 1}

${ }^{(1,2)}$ Sampling number and localities sites, refer to Fig. $1 ;{ }^{(3)}$ running sample label for this paper; ${ }^{(4)}$ field/laboratory number; ${ }^{(5)}$

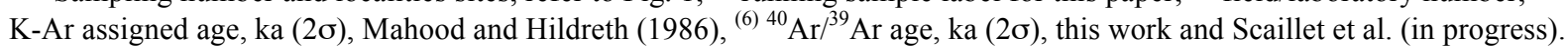




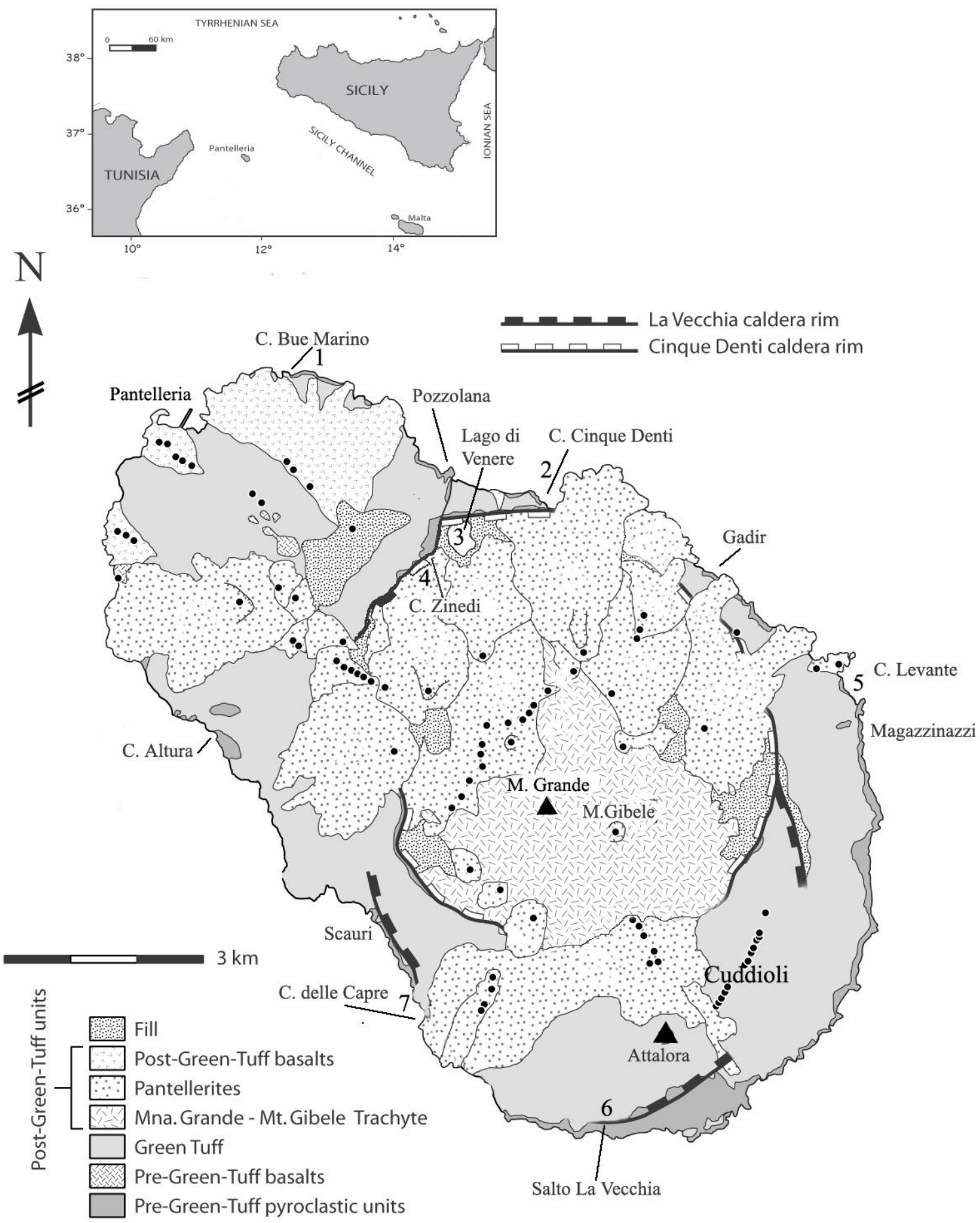




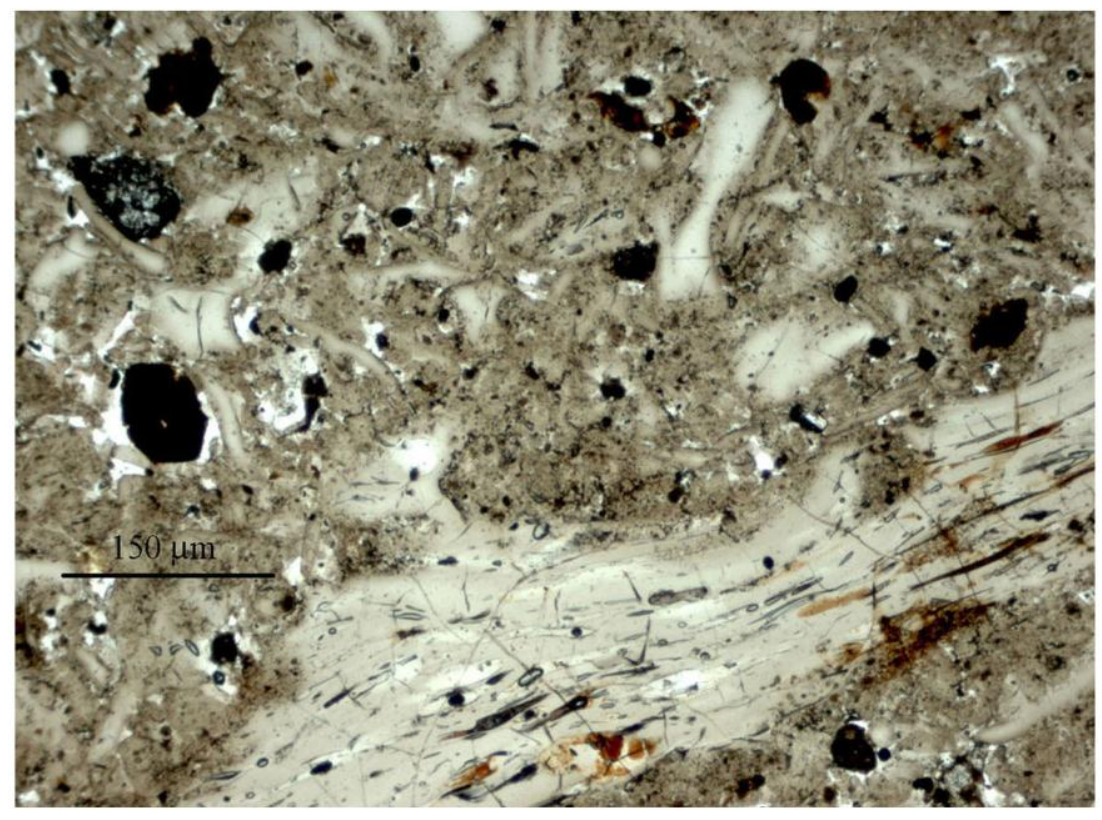

Fig. 2 


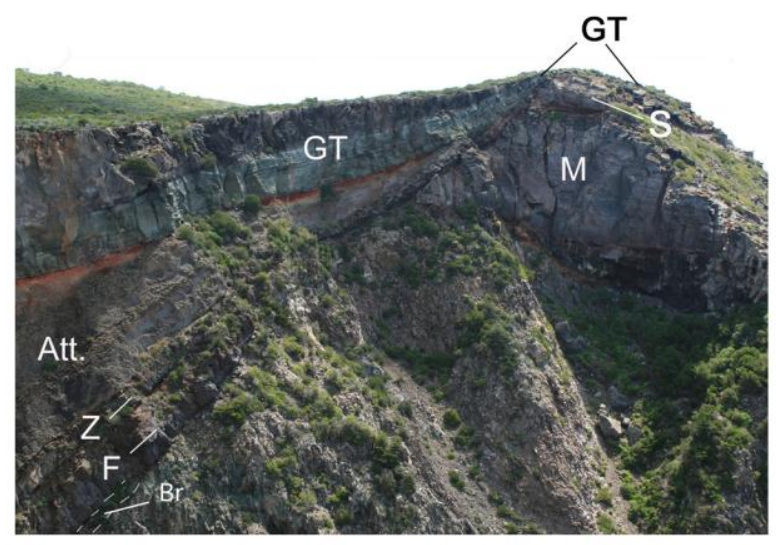

Fig 3 

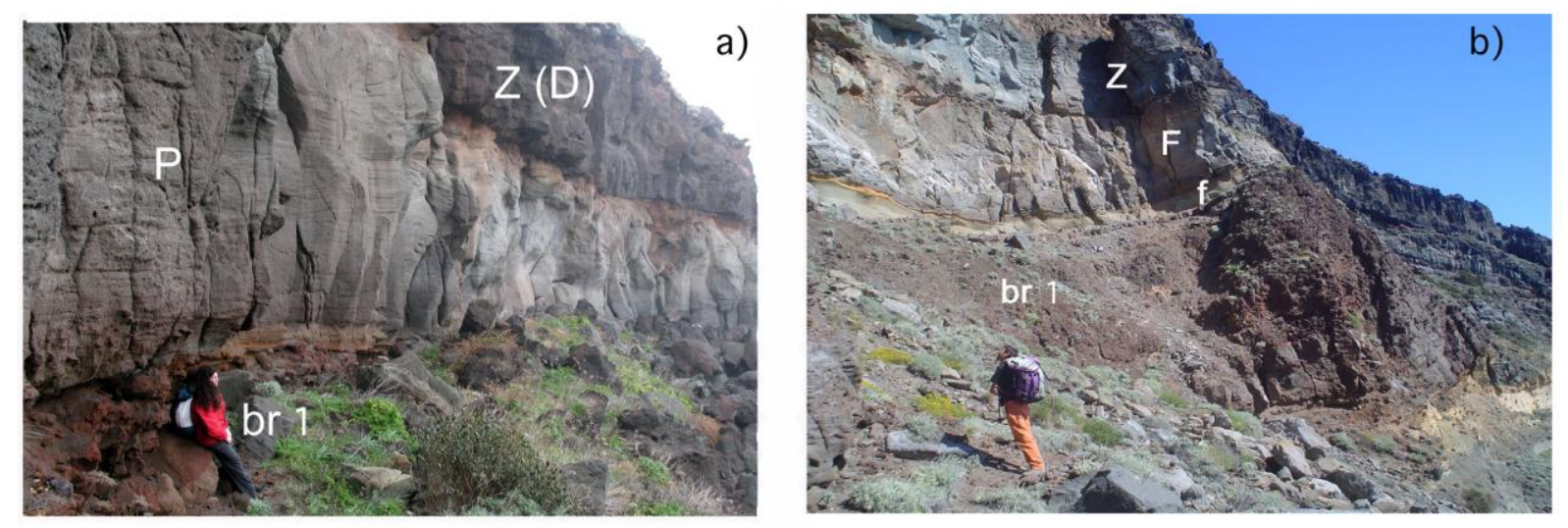

Fig, 4 


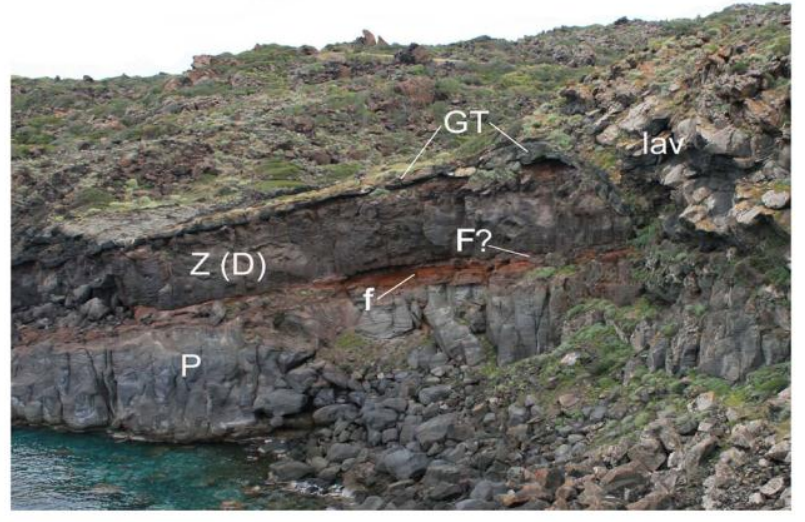

Fig. 5 


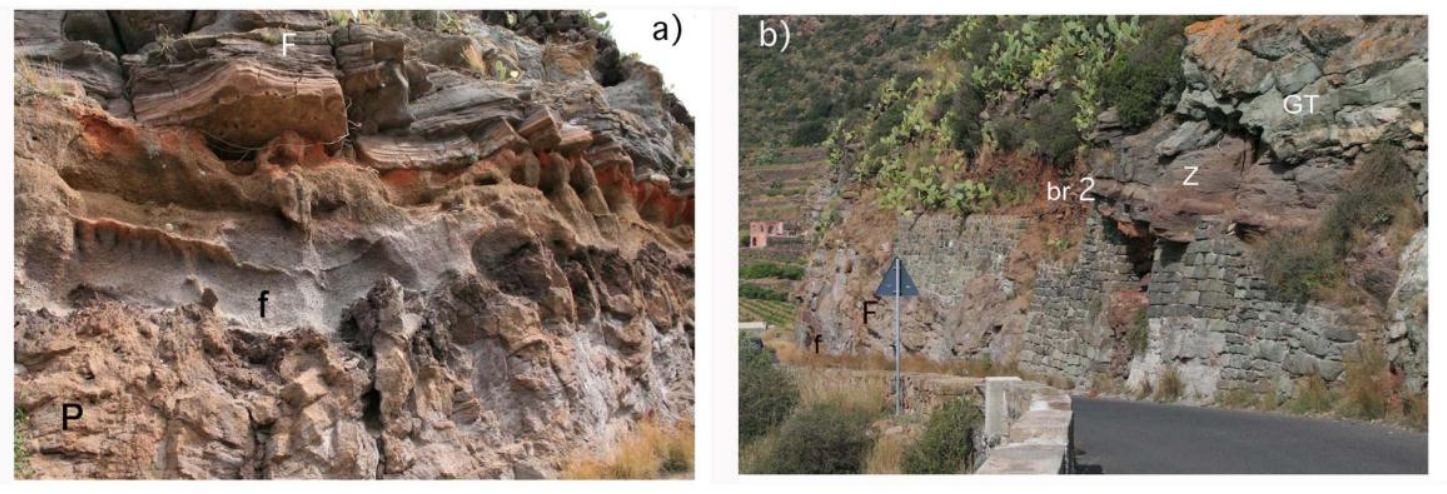

Fig. 4 

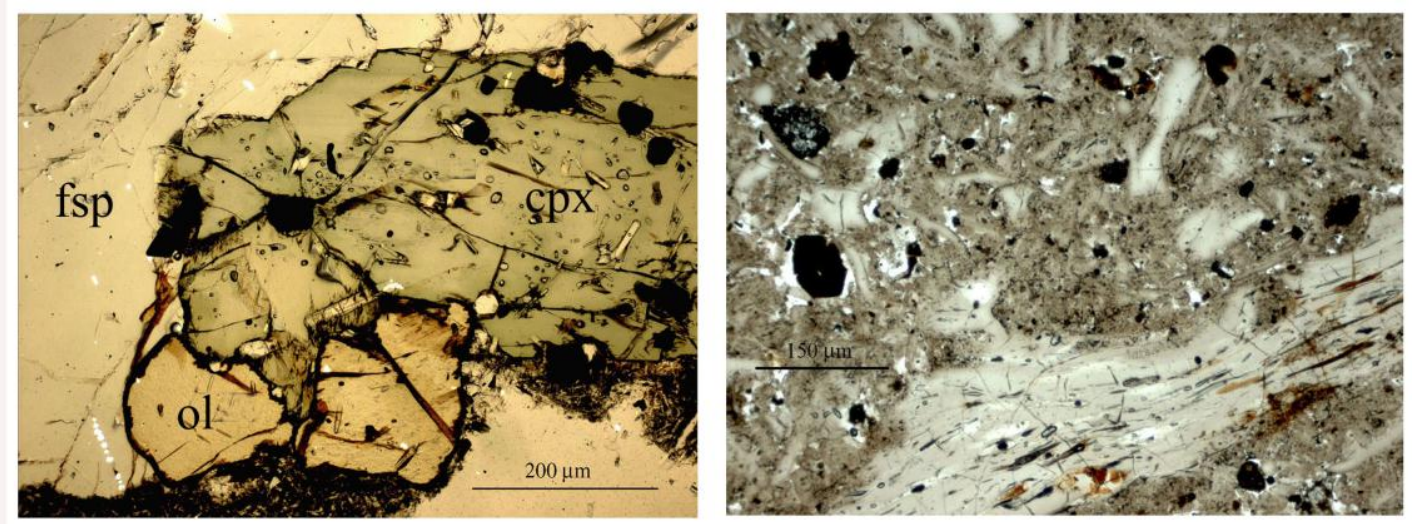

Fig 4 

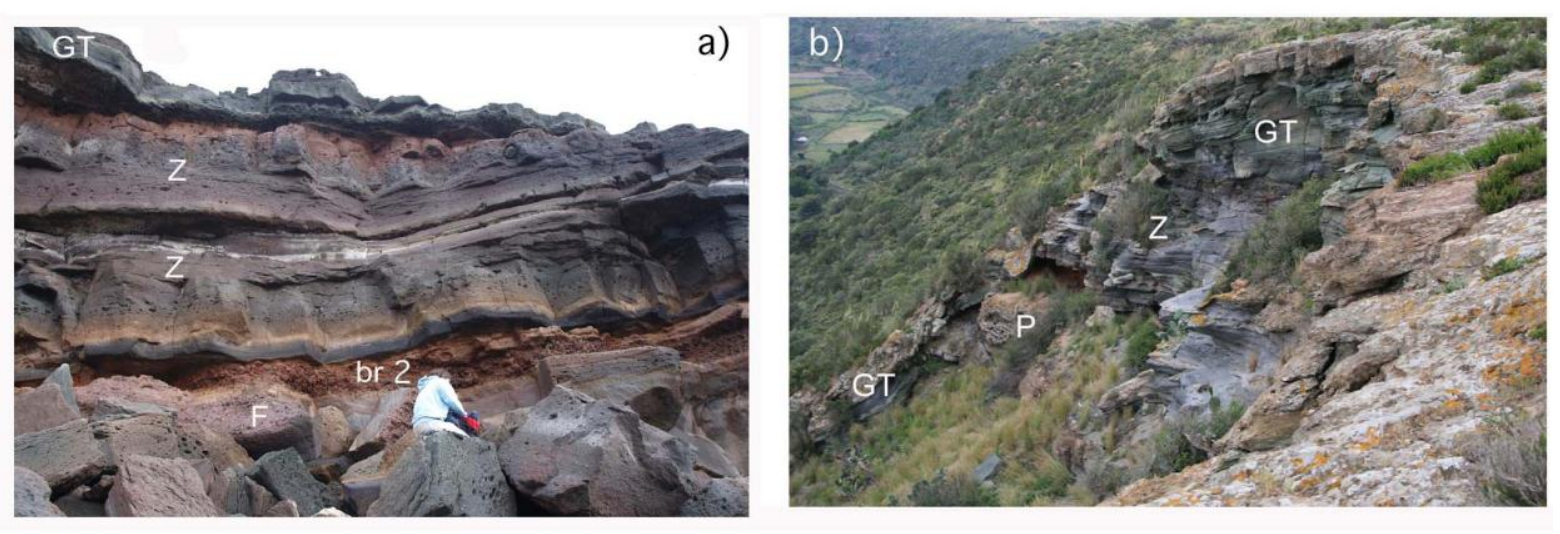

Fig. 6 


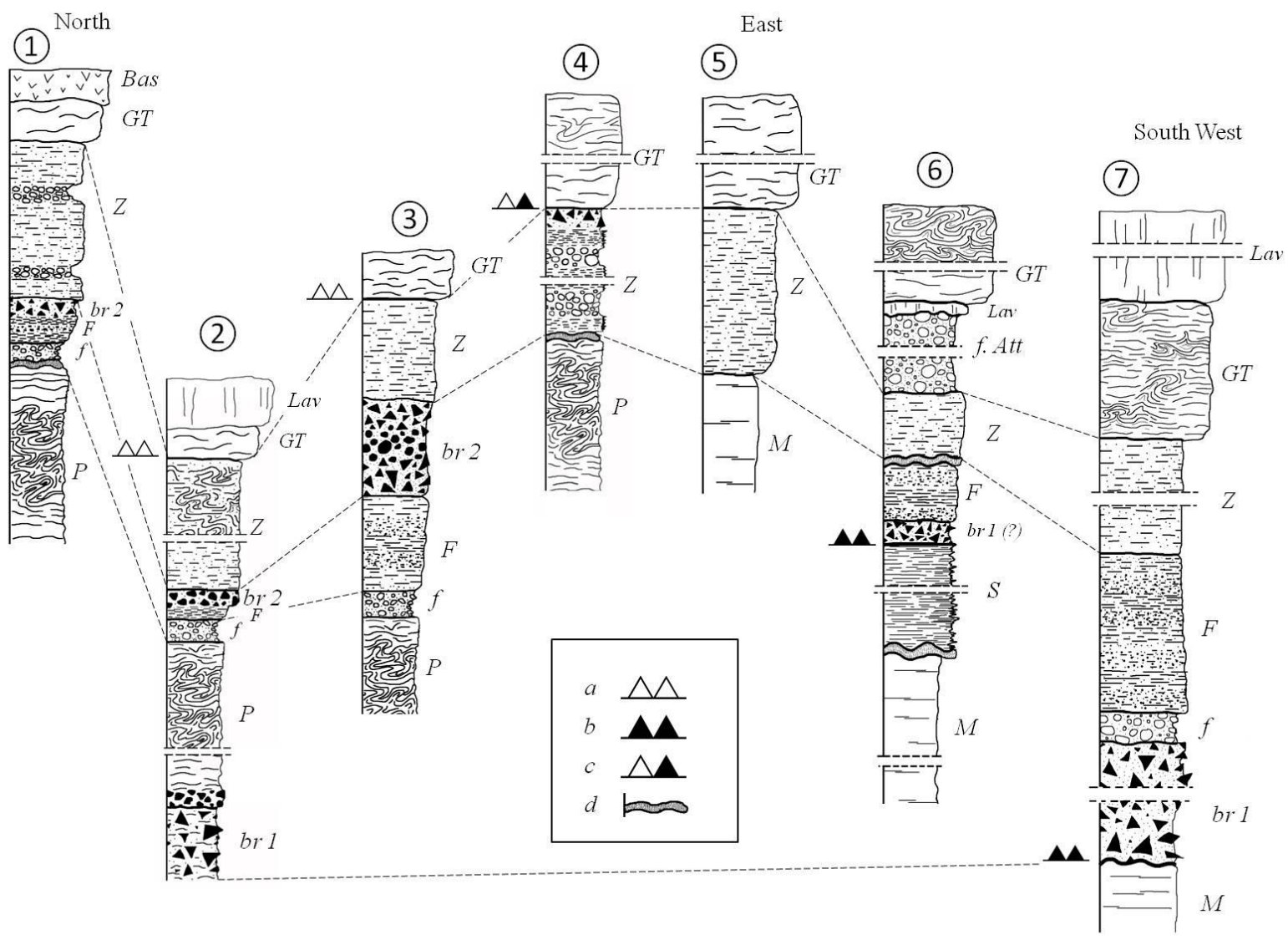




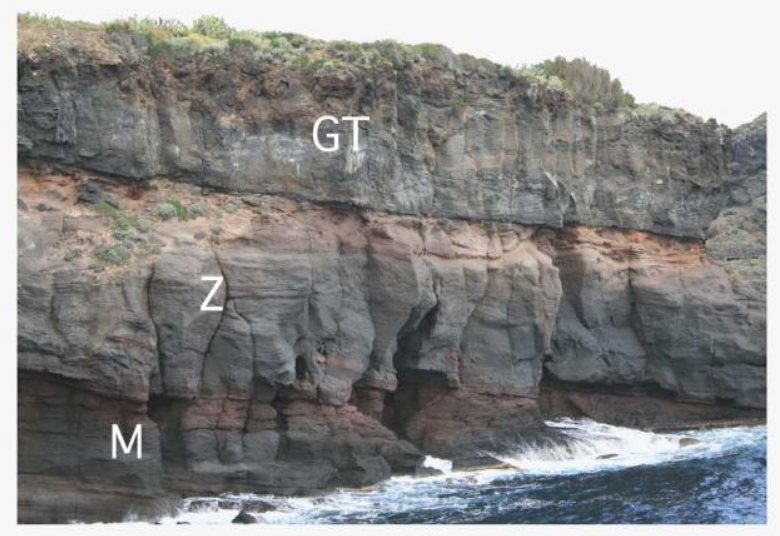

Fig. 7 